\title{
Nanocomposite-Based Aminated Polyethersulfone and Carboxylate Activated Carbon for Environmental Application. A Real Sample Analysis
}

\author{
Noof A. Alenazi ${ }^{1}$, Mahmoud A. Hussein ${ }^{1,2, *}{ }^{\mathbb{C}}$, Khalid A. Alamry ${ }^{1, *}$ and Abdullah M. Asiri ${ }^{1,3}$ \\ 1 Department of Chemistry, Faculty of Science, King Abdulaziz University, P.O. Box 80203, \\ Jeddah 21589, Saudi Arabia; noof0988@hotmail.com (N.A.A.); ceamr3@gmail.com (A.M.A.) \\ 2 Polymer Chemistry Lab., Chemistry Department, Faculty of Science, Assiut University, Assiut 71516, Egypt \\ 3 Center of Excellence for Advanced Materials Research (CEAMR), King Abdulaziz University, P.O. Box 80203, \\ Jeddah 21589, Saudi Arabia \\ * Correspondence: maabdo@kau.edu.sa or mahmali@aun.edu.sa (M.A.H.); kaalamri@kau.edu.sa (K.A.A.)
}

Received: 16 April 2018; Accepted: 11 May 2018; Published: 15 May 2018

\begin{abstract}
Aminated polyethersulfone (PES- $\mathrm{NH}_{2}$ ) has been synthesized and used with carboxylated activated carbon (AC-COOH) as an adsorbent using two different methods: in situ and ex situ techniques. The chemical modification of polyethersulfone (PES) to introduce $-\mathrm{NH}_{2}$ functions was used to overcome the hydrophobicity of PES which maximizes its use in water treatment applications whereas applying $\mathrm{AC}-\mathrm{COOH}$ to this polymer provides a promising effective method as an adsorbent-separation technique to remove dye pollutants from wastewater. The structure and characterization of aminated polyethersulfone with carboxylated activated carbon ( $\left.\mathrm{PES}-\mathrm{NH}_{2}-\mathrm{AC}-\mathrm{COOH}\right)$ were identified using proton nuclear magnetic resonance $\left({ }^{1} \mathrm{H}-\mathrm{NMR}\right)$, Fourier transform infrared (FT-IR spectroscopy), X-ray diffraction (XRD), thermal analysis (TA), and a scanning electron microscopy (SEM). The performance of PES- $\mathrm{NH}_{2}$ in situ and ex situ with AC-COOH was tested for the adsorption of cationic (methylene blue) and anionic (acid red 1) dyes from an aquatic environment. The results of the study showed a better thermal stability for the PES- $\mathrm{NH}_{2}$ with $20 \% \mathrm{AC}-\mathrm{COOH}$ with both in situ and ex situ techniques as well as an excellent adsorption performance in comparison with the bare $\mathrm{PES}-\mathrm{NH}_{2}$. The resultant polymers displayed significantly high adsorption rates for the acid red dye $(60 \%$ and $68 \%)$ and methylene blue dye $(61 \%$ and $88 \%)$ by $\mathrm{PES}-\mathrm{NH}_{2}$ with $\mathrm{AC}-\mathrm{COOH}$ using in situ and ex situ techniques, respectively, in comparison with the control (PES- $\mathrm{NH}_{2}$ ) which showed lower adsorption rates for both dyes $(21 \%$ for acid red and 33\% for methylene blue). Lastly, the study experimental measurements found the most suitable model to describe the kinetic behavior of the acid red dye adsorption by our developed polymer (by PES- $\mathrm{NH}_{2}$ with $\mathrm{AC}-\mathrm{COOH}$ ) to be the pseudo-second-order kinetic model.
\end{abstract}

Keywords: dye adsorption; ex situ and in situ techniques; adsorptive behavior; activated carbon; nanocomposites

\section{Introduction}

Pollutants including heavy metals (mercury, cadmium, lead, chromium, etc.) and organic compounds (including dyes, personal care products, and pharmaceutical substances) are considered hazardous contaminates when they reach water streams for both human and living organisms [1]. Among all these pollutants, dyes are considered one of the most persist pollutants in water due to its low degradation and high stability in the aquatic environment. Dyes have two fundamentals parts: chromophores, which are responsible for their colors, and auxochromes, which are responsible for their binding affinity towards fibers [2,3]. Dyes are commonly used in food, textile, pharmaceutical, 
cosmetic, and papers productions. In the textile sector, almost 200,000 tons of dye is lost as wastes during the dying processes for the textile synthesis [4]. Most of these waste dyes present in the aquatic environment for a long time due to their high stability to light and temperature. The high demand for the textile products leads to a high demand for synthetic dyes, and wastewaters contaminated with dyes are considered one of the most significant causes for pollutions in the aquatic environment. Additionally, synthetic dyes are considered a great risk because they are highly toxic to the aquatic environment and are carcinogenic to humans. More specifically, azo dyes have been discovered to have mutagenic effects because of their biotransformation derivatives once they enter the body by digestion. The biotransformation of zo dyes occurs via the liver enzymes to form $N$-hydroxylamine compounds, which have been found to cause damage to DNA. Additionally, dyes have been linked to many health illness issues related to kidneys, brain, liver, as well as central nervous and reproductive systems $[4,5]$. There are different techniques to remove these dyes from wastewater including adsorptions techniques. The adsorption method is known to be the most effective and low-cost methods, and there are different types of adsorbents including fly ash, lignite, activated carbon black (AC), sawdust, coal, and wood [6]. Activated carbon is often used as an adsorbent due to its variability and low cost [6,7]. However, in order to enhance the use of AC as adsorbents, AC particles should be used with polymeric materials [8,9].

Polyethersulfone (PES) is a well-known polymer that has been applied to various adsorbents-separation techniques including dyes adsorption [6] and other organic compounds adsorption [8]. This wide use of PES is because of its high thermal, mechanical, and chemical properties [4]. However, the hydrophobicity of PES is considered one of the drawbacks that limit its use. The additional of hydrophilic functions to PES (including amino, carboxylic, sulfonic, and so forth) could be an effective method to overcome its hydrophobicity [10]. In this work, PES has been chemically modified to PES- $\mathrm{NH}_{2}$ in order to improve its hydrophobicity. The structure PES- $\mathrm{NH}_{2}$ was confirmed using proton nuclear magnetic resonance $\left({ }^{1} \mathrm{H}-\mathrm{NMR}\right)$ and Fourier transform Infrared (FT-IR) spectroscopy. The AC-COOH fine particles were then fabricated in our lab and they have been used with PES- $\mathrm{NH}_{2}$ using two methods: the in situ and ex situ techniques. Then, the PES- $\mathrm{NH}_{2}$ with $\mathrm{AC}-\mathrm{COOH}$ structures were identified and characterized using FT-IR spectroscopy, X-ray diffraction analysis (XRD), thermal analysis (TA), and scanning electron microscopy (SEM) technique. The performance of PES- $\mathrm{NH}_{2}$ in situ and ex situ with $\mathrm{AC}-\mathrm{COOH}$ was tested in order to examine its performance in removing both cationic (methylene blue) and anionic (acid red 1) dyes from the aquatic environment. Because of its high adsorption capacity $\left(q_{\mathrm{e}}\right)$ in comparison with methylene blue, an acid red dye was used to test the adsorption capability of the solid phase (SP) of PES- $\mathrm{NH}_{2}-\mathrm{AC}-\mathrm{COOH}$ under different parameters including $\mathrm{pH}$, contact time, and temperature. Then, the kinetics behaviors and thermodynamic characteristics of acid red adsorption onto PES- $\mathrm{NH}_{2}$ in situ and ex situ with $\mathrm{AC}-\mathrm{COOH}$ were further studied. Finally, two real environmental samples from the Red Sea and tap water were spiked with acid red and used to explore the environmental applications of $\mathrm{PES}-\mathrm{NH}_{2}$ in situ and ex situ with $\mathrm{AC}-\mathrm{COOH}$ in removing the acid red dye from the aqueous environment.

\section{Experimental}

\subsection{Materials}

All chemicals and solvents were used as they were obtained from their companies with no purification. The polyethersulfone (PES) was purchased from Solvay Chemicals Limited, Panoli, India. The deuterated dimethylsulfoxide (DMSO- $\left.\mathrm{d}_{6}\right)(99.8 \%)$, chloroform $(99.8 \%)$, dichloromethane (DCM) $(99.8 \%)$, and acid red were purchased from the Sigma-Aldrich Company, Milwaukee, WI, USA. The potassium iodide (KI), sodium hydroxide $(\mathrm{NaOH})$, Tin (II) chloride $\left(\mathrm{SnCl}_{2}\right)$, hydrochloric acid $(\mathrm{HCl})(37 \%)$, sulfuric acid $\left(\mathrm{H}_{2} \mathrm{SO}_{4}\right)(95-97 \%)$, and nitric acid $\left(\mathrm{HNO}_{3}\right)(65 \%)$ were all obtained from BDH Ltd., Poole, UK. For the preparation of standard and stock solutions, the deionized water was purchased from Millipore Milli-Q Plus, Milford, MA, USA. 


\subsection{Reagents}

Acid red was prepared with $1000 \mu \mathrm{g} / \mathrm{mL}$ as a stock solution. The stock solution was further diluted to $10-100 \mu \mathrm{g} / \mathrm{mL}$ using fresh deionized water. Britton-Robinson buffer (BR) with $\mathrm{pH}$ of 2 to 11 and $\mathrm{HCl}$ solution of $0.1 \mathrm{~mol} / \mathrm{L}$ were prepared in order to be used as extraction solvents during the acid red adsorption utilizing the polymer solid phase (SP) technique.

\subsection{Methods}

\subsubsection{Synthesis of PES- $\mathrm{NH}_{2}$}

PES- $\mathrm{NH}_{2}$ was prepared with two steps process reactions, a nitration reaction followed by a reduction reaction, following a procedure done by Haider et al. [11] as shown in Scheme 1a. First for the nitration reaction, $2 \mathrm{~g}$ of PES was added to a mixture of $25 \mathrm{~mL}\left(\mathrm{H}_{2} \mathrm{SO}_{4}\right)$ and $10 \mathrm{~mL}$ of $\left(\mathrm{HNO}_{3}\right)$ at $65^{\circ} \mathrm{C}$ for $5 \mathrm{~h}$. Then, the reaction mixture solution was ended by pouring the reaction solution into an ice bath filled with cold deionized distilled water (D.D.W). The solution was then filtered and washed with $\mathrm{NaOH}(2 \mathrm{M})$ and several times with D.D.W. Finally, the PES- $\mathrm{NO}_{2}$ particles were then dried at a temperature of $30{ }^{\circ} \mathrm{C}$ for two days. For the reduction step, $2 \mathrm{~g}$ of $\mathrm{PES}-\mathrm{NO}_{2}$ were suspended in $25 \mathrm{~mL}$ of chloroform in a three neck rounded flask attached with condenser. An amount of $25 \mathrm{~g}$ of $\mathrm{SnCl}_{2}$ and $1.67 \mathrm{~g} \mathrm{KI}$ were suspended in $100 \mathrm{~mL}$ of a mixture of $\mathrm{HCl}$. Glacial acetic acid (GAA) (2:1) was then added slowly to ${ }^{\circ} \mathrm{C}$ PES-NO $\mathrm{NO}_{2}$ solution at $65^{\circ} \mathrm{C}$. The reaction mixture solution was then continued at a temperature of $65^{\circ} \mathrm{C}$ for $6 \mathrm{~h}$. Finally, the reaction solution was left at room temperature to cool the solution dawn and it was then poured into a $\mathrm{NaOH}(2 \mathrm{M})$ bath, filtered, and washed with D.D.W for several times until the $\mathrm{pH}$ became around 8 to 7 . The $\mathrm{PES}-\mathrm{NH}_{2}$ particles were obtained and dried at $30{ }^{\circ} \mathrm{C}$ for two days.

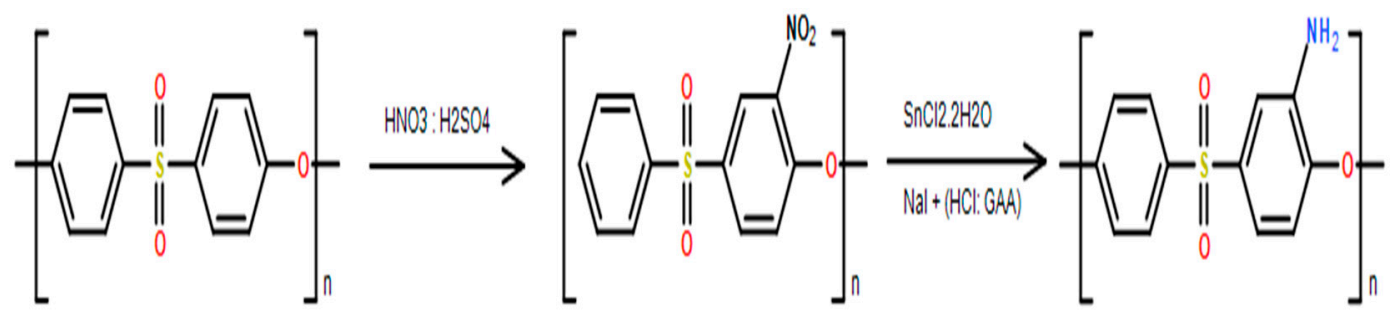

(a)
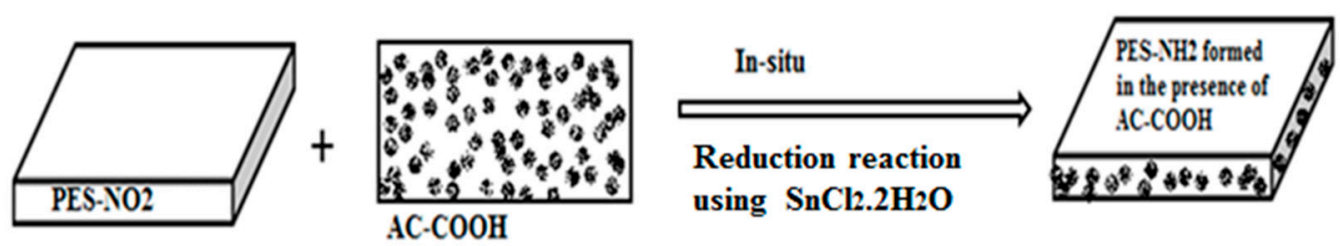

(b)

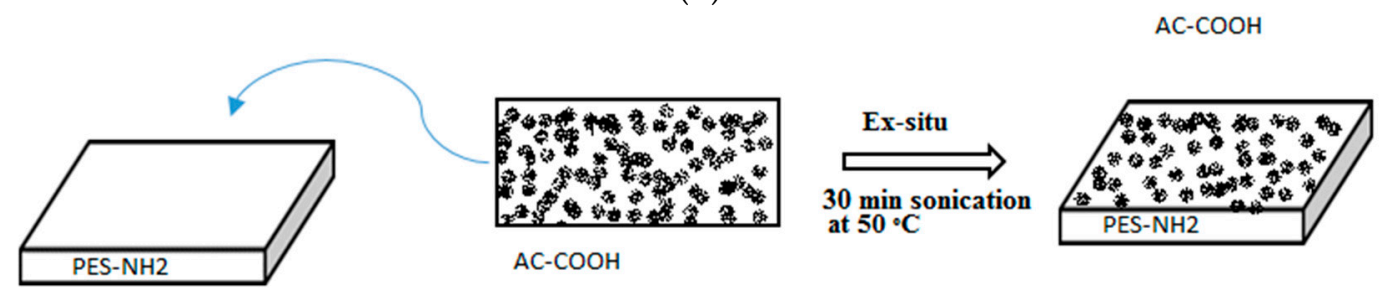

(c)

Scheme 1. The preparation of PES- $\mathrm{NH}_{2}(\mathbf{a}), \mathrm{PES}-\mathrm{NH}_{2}$ in situ with AC-COOH inside the polymer matrix (b), and PES- $\mathrm{NH}_{2}$ ex situ with AC-COOH onto the polymer matrix surface (c). 


\subsubsection{Preparation of AC-COOH}

$\mathrm{AC}-\mathrm{COOH}$ was fabricated, the carboxylic functional groups introduced to the surface of AC, following a procedure done by Marwani et al. [12]. In this work, $5 \mathrm{~g}$ of AC was suspended in $150 \mathrm{~mL}$ of $\mathrm{HNO}_{3}$ with a concentration of $32.5 \%(\mathrm{v} / \mathrm{v})$ under stirring and heating at $60{ }^{\circ} \mathrm{C}$ for $5 \mathrm{~h}$. The resultant particles were filtered and washed with deionized distilled water (D.D.W). Then, the AC-COOH particles were dried using an oven vacuum set at a temperature of $80^{\circ} \mathrm{C}$ for $8 \mathrm{~h}$.

\subsubsection{Preparation of PES- $\mathrm{NH}_{2}$ with PES with $\mathrm{AC}-\mathrm{COOH}$ by the In Situ Technique}

For PES- $\mathrm{NH}_{2}$ in situ with AC-COOH, different concentrations of AC-COOH $(2,5,10$, and $20 \mathrm{wt} \%)$ were added to $2 \mathrm{~g}$ of $\mathrm{PES}-\mathrm{NO}_{2}$ prior to the synthesis of $\mathrm{PES}-\mathrm{NH}_{2}$ as shown in Scheme $1 \mathrm{~b}$. This approach was explored because of its simplicity and the high dispersion capability of $\mathrm{AC}-\mathrm{COOH}$ particles inside the polymer matrix. The drawback of this approach is that $\mathrm{AC}-\mathrm{COOH}$ particles could have less reactivity than the ex situ technique with pollutants.

\subsubsection{Preparation of PES- $\mathrm{NH}_{2}$ with $\mathrm{AC}-\mathrm{COOH}$ by the Ex Situ Technique}

An amount of $2 \mathrm{~g}$ of PES- $\mathrm{NH}_{2}$ particles was suspended first in DCM for $5 \mathrm{~min}$ at $50{ }^{\circ} \mathrm{C}$ in an ultrasonic bath with different concentrations of $\mathrm{AC}-\mathrm{COOH}(2,5,10$, and $20 \mathrm{wt} \%)$. Then, the mixture was sonicated with an ultrasonic probe for $30 \mathrm{~min}$. The mixture transferred into a glass supporting surface and dried at room temperature for 1 day as shown in Scheme 1c. This approach is used because it is more applicable for large-scale applications than in the situ method, and the ex situ method allowed the direct interactions of $\mathrm{AC}-\mathrm{COOH}$ particles with pollutants that were present in the wastewaters. The drawback of this approach is that the $\mathrm{AC}-\mathrm{COOH}$ particles have less stability in the polymeric matrix than in the in situ method.

\subsection{Techniques}

The spectrophotometric measurements were acquired using a spectrophotometer of a Perkin-Elmer UV-Visible (Lambda 25 model from the USA) with a UV range of 190-1100 nm equipped with quartz cell (10 $\mathrm{mm}$ as path width). For the $\mathrm{pH}$ test solution and measurements, a pH Orion meter (EA 940 model) was used. The FT-IR spectra were obtained with a range of $4000 \mathrm{~cm}^{-1}-450 \mathrm{~cm}^{-1}$ wavenumbers using a Nicolet (6700) FT-IR Spectrometer from the Thermo Electron Corporation. ${ }^{1} \mathrm{H}-\mathrm{NMR}$ analysis was acquired in DMSO- $\mathrm{d}_{6}$ on a Brucker DPX $600 \mathrm{MHz}$ spectrometer using tetramethylsilane (TMS) as the internal standard at room temperature. For the XRD analysis, powder XRD data were achieved utilizing an electronic Philips diffractometer (PW 103/00 model) equipped with radiation of Ni-filtered $\mathrm{Cu} \mathrm{K} \alpha$, in which the range of $2 \theta$ is $5^{\circ}-80^{\circ}$. For the SEM analysis, the morphology of the PES- $\mathrm{NH}_{2}$ and $\mathrm{PES}-\mathrm{NH}_{2}-\mathrm{AC}-\mathrm{COOH}$ was examined by a SEM using Quanta, FEI.

\subsection{Adsorption Technique for Dyes}

An amount of $0.02 \mathrm{~g}$ of PES- $\mathrm{NH}_{2}$ with AC-COOH ex situ and PES- $\mathrm{NH}_{2}$ with AC-COOH in situ were measured in a $20 \mathrm{~mL}$ solution containing both acid red with a concentration of $20 \mathrm{mg} / \mathrm{L}$ and $\mathrm{HCl}$ with a concentration of $0.1 \mathrm{~mol} / \mathrm{L}$, and then the solution was shaken for $1 \mathrm{~h}$ using a shaker device. Then, the supernatant was separated from the solid residues and taken up in order to be photometrically measured with respect to a blank sample [13]. The adsorption of acid red was calculated by subtracting the absorption of acid red before $\left(A_{\mathrm{b}}\right)$ from the absorption of acid red after $\left(A_{\mathrm{f}}\right)$ it was adsorbed by the polymer solid phase. The calculations of the percentage of sorption $(\% \mathrm{E})$, the acid red retention $\left(q_{\mathrm{e}}\right)$ at equilibrium/mass of the solid sorbent $(\mathrm{g} / \mathrm{mol})$, as well as the coefficient of distribution $\left(K_{d}\right)$ for the adsorbed acid red onto the PES- $\mathrm{NH}_{2}$ with $\mathrm{AC}-\mathrm{COOH}$ were all determined as they were described previously [13]. Three repeated measurements were done for $K_{\mathrm{d}}$ and \%adsorption, and the average values were taken in which the precision differed $\pm 2 \%$ only. The effect of the shaken 
time, as well as temperature for the acid red retention on PES- $\mathrm{NH}_{2}$ with $\mathrm{AC}-\mathrm{COOH}$ solid sorbents, were investigated in detail.

\subsection{Environmental Applications and Sample Collection}

Water samples from the Red Sea and tap water were collected in order to assess the performance of PES- $\mathrm{NH}_{2}$ with $\mathrm{AC}-\mathrm{COOH}$ solid sorbents for the acid red adsorption and recovery. The Red Sea water sample used in this study was collected from the Jeddah coast in Saudi Arabia whereas the tap water was obtained from the chemistry labs at the King Abdul-Aziz University, Jeddah city, Saudi Arabia. The samples were filtered through a membrane filter with $0.45 \mu \mathrm{m}$ and the samples then preserved with Teflon bottles in a dark area with a temperature of $5{ }^{\circ} \mathrm{C}$. Samples of $100 \mathrm{~mL}$ were $\mathrm{pH}$ modified to a $\mathrm{pH}$ of 1 using an $\mathrm{HCl}$ solution that had a concentration of $0.1 \mathrm{~mol} / \mathrm{L}$ and then they were passed through the polymer solid phase. Then, the recovered acid red was calculated spectrophotometrically.

\section{Results and Discussions}

\subsection{Characterization of $\mathrm{PES}-\mathrm{NH}_{2}$ with $\mathrm{AC}-\mathrm{COOH}$}

${ }^{1} \mathrm{H}-\mathrm{NMR}$ was used to confirm the chemical structure of PES, PES-NO $\mathrm{NO}_{2}$, and PES-NH $\mathrm{N}_{2}$, respectively as shown in Figure 1. According to ${ }^{1} \mathrm{H}-\mathrm{NMR}$ of the PES spectrum, two distinct doublet peaks were noticed at $7.9 \mathrm{ppm}$ and $7.2 \mathrm{ppm}$ accounting for two protons ( $\mathrm{a}$ and $\mathrm{b}$ ), respectively. After nitration, the ${ }^{1} \mathrm{H}-\mathrm{NMR}$ of PES- $\mathrm{NO}_{2}$ spectrum showed three distinct peaks. The first peak was a double at $7.7 \mathrm{ppm}$ (c) because of the ortho coupling for the proton that appeared at $8.8 \mathrm{ppm}$. The second distinct peak which appeared at $8.4 \mathrm{ppm}(\mathrm{d})$ was a doublet of the two doublets of the protons that were ortho and meta coupled (at $8.8 \mathrm{ppm}$ and $7.7 \mathrm{ppm}$, respectively), which suggested that the nitration of PES had occurred. The third peak, which appeared at $8.8 \mathrm{ppm}(\mathrm{e})$, was a doublet because of the proton that showed meta coupling a shown in Figure 1. Therefore, it can be concluded that the nitration occurred at the carbon that was on the ortho position to the ether oxygen. After the reduction of PES- $\mathrm{NO}_{2}$, the ${ }^{1} \mathrm{H}-\mathrm{NMR}$ of PES- $\mathrm{NH}_{2}$ spectrum showed four distinct peaks that were shifted to a lower filed because of the donating electron nature of the amine, unlike the nitro functions which have an electron withdrawing nature. The first peak of the four amine peaks was a single peak and it was noticed at $5.5 \mathrm{ppm}$ rising from the amine protons. The second peak was noticed as a doublet at $6.8 \mathrm{ppm}$ and this is because of the presence of the proton that showed ortho coupling. The third distinct peak was a doublet of doublets at $6.9 \mathrm{ppm}$ because of the two protons that showed ortho and meta couplings. Lastly, the fourth peak was noticed as a doublet at $7.2 \mathrm{ppm}$ and this is because of the presence of the proton that showed meta coupling. This ${ }^{1} \mathrm{H}-\mathrm{NMR}$ data were in agreement with the previous reported data [14].

The chemical structures of PES, PES- $\mathrm{NO}_{2}$, and PES- $\mathrm{NH}_{2}$ were further confirmed using FT-IR spectroscopy as shown in Figure 2. The chemical structure of the PES contains three important functions including benzene, ether, and sulfone. The presence of benzene rings should exhibit three peaks in the range of $1600 \mathrm{~cm}^{-1}$ to $1400 \mathrm{~cm}^{-1}$, and, in the PES spectrum, the three peaks were observed at $1576 \mathrm{~cm}^{-1}$, $1483.7 \mathrm{~cm}^{-1}$, and $1405 \mathrm{~cm}^{-1}$. The presence of the ether function was confirmed due to the presence of its two starching peaks at $1319 \mathrm{~cm}^{-1}$, as well as $1296 \mathrm{~cm}^{-1}$. The two starching peaks indicating the presence of the sulfone group were also noticed at $1144 \mathrm{~cm}^{-1}$ and $1100 \mathrm{~cm}^{-1}$. Our data of the PES spectrum came in agreement with previously reported studies on PES FT-IR analysis [12,15]. The FT-IR spectrum of PES-NO $\mathrm{N}_{2}$ showed an asymmetric peak at $1531 \mathrm{~cm}^{-1}$ and a symmetrical peak at $1342 \mathrm{~cm}^{-1}$ which indicate the attachment of the $-\mathrm{NO}_{2}$ functions on the PES. After the reduction of the $-\mathrm{NO}_{2}$ groups to $-\mathrm{NH}_{2}$ groups, the FT-IR of PES- $\mathrm{NH}_{2}$ spectrum exhibited the formation of $-\mathrm{NH}_{2}$ by showing two peaks at $3344 \mathrm{~cm}^{-1}$, as well as $3451 \mathrm{~cm}^{-1}$, and the deformation of $-\mathrm{NH}_{2}$ by showing a peak at $1622 \mathrm{~cm}^{-1}$. This confirms the attachment of the amine functions on PES. Both our FT-IR of the PES-NO $\mathrm{NO}_{2}$ and $\mathrm{PES}-\mathrm{NH}_{2}$ spectra came in agreement with a previously reported study [12]. The FT-IR spectra of $\mathrm{PES}-\mathrm{NH}_{2}$ with different concentrations of $\mathrm{AC}-\mathrm{COOH}$ using the in situ and ex situ techniques are shown in Figure 3a,b, respectively. 
In Figure 3a, it can be clearly seen that as the concentrations of $\mathrm{AC}-\mathrm{COOH}$ increased, the shifting of the amine stretching peaks was noticed, which suggests that the interactions between $\mathrm{AC}-\mathrm{COOH}$ and PES- $\mathrm{NH}_{2}$ were formed. In addition, it was also noticed that the effects of increasing the concentrations of AC- $\mathrm{COOH}$ in PES- $\mathrm{NH}_{2}$ resulted in overlapping peaks between the amine and $-\mathrm{OH}$ for the acid peaks until it became one peak at $3354 \mathrm{~cm}^{-1}$ for using $10 \mathrm{wt} \%$ of AC-COOH and at $3367 \mathrm{~cm}^{-1}$ for using $10 \mathrm{wt} \%$ of AC- $\mathrm{COOH}$ instead of two peaks for the amine functions. We suggest that the noncovalent interactions such as intermolecular forces, dipole-dipole, hydrogen bonding, and Van der Waals interactions between $\mathrm{AC}-\mathrm{COOH}$ and $\mathrm{PES}-\mathrm{NH}_{2}$ took place during the synthesis of the polymer through the in situ technique. However, when the PES- $\mathrm{NH}_{2}$ was coated with $\mathrm{AC}-\mathrm{COOH}$ on its surface through the ex situ technique, the noncovalent interactions were weaker, which explained the FT-IR spectrum in Figure $3 b$, in which less shifting was seen between the amine stretching peaks during the presence of $\mathrm{AC}-\mathrm{COOH}$ on the surface of the PES-NH $\mathrm{N}_{2}$.
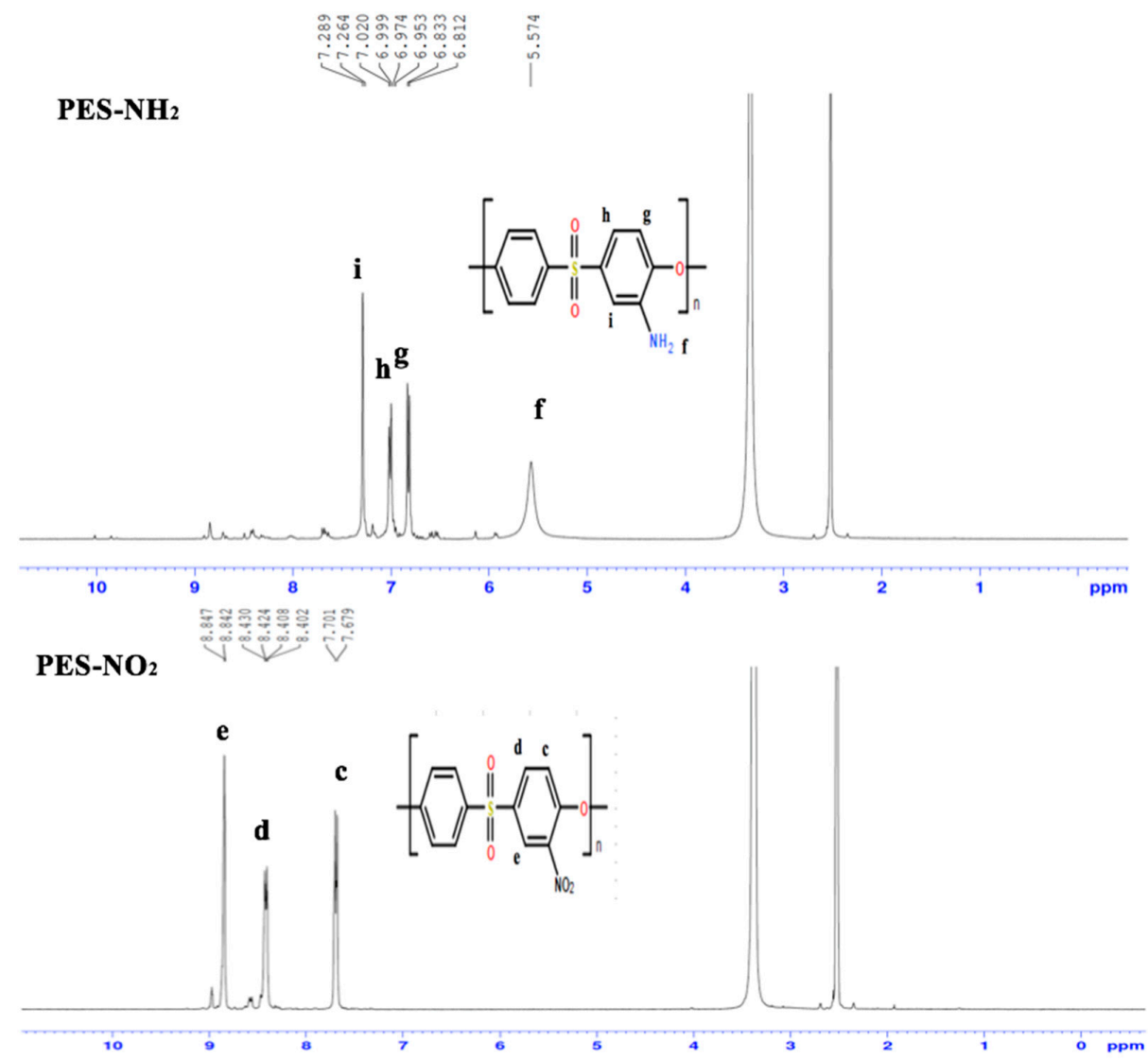

PES
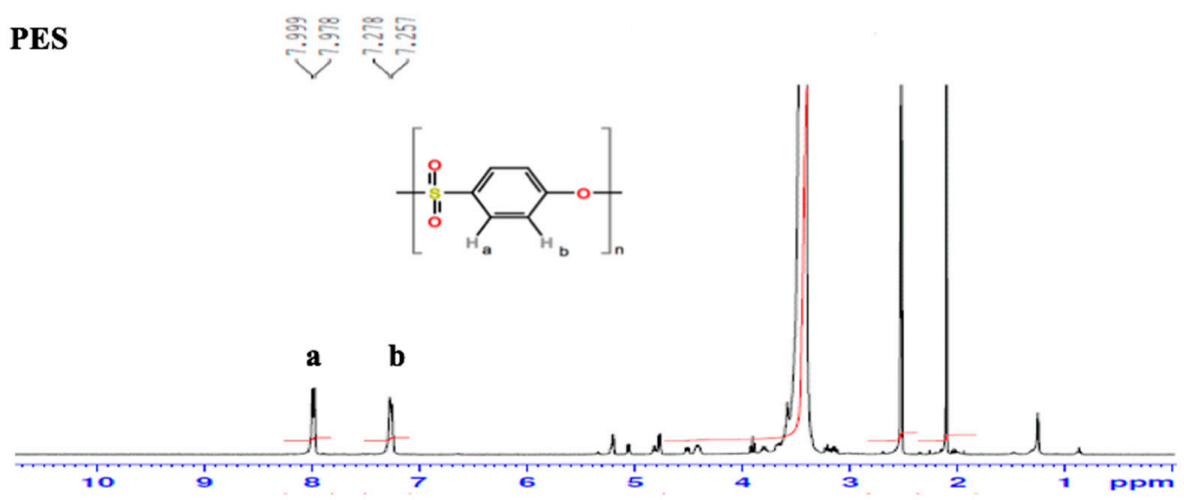

Figure 1. The ${ }^{1} \mathrm{H}-\mathrm{NMR}$ of PES, PES- $\mathrm{NO}_{2}$, and PES- $\mathrm{NH}_{2}$. 


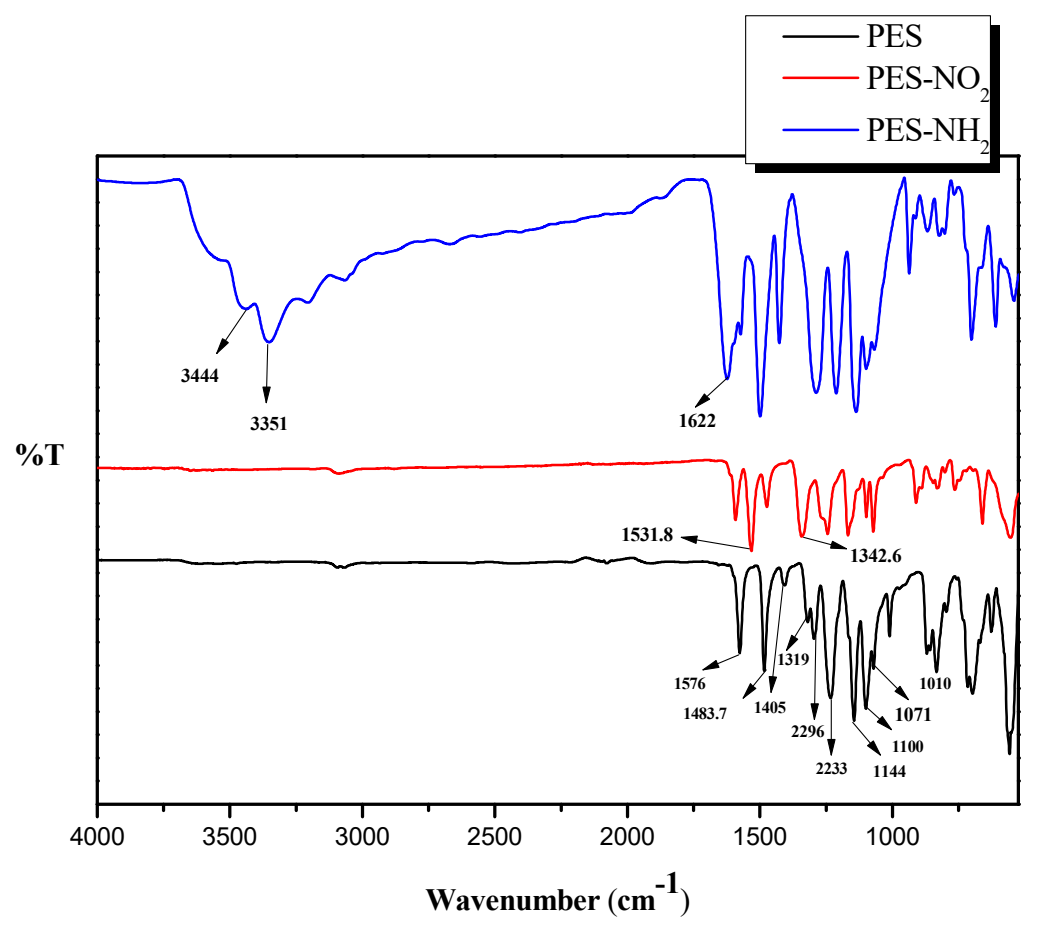

Figure 2. The FT-IR spectrum of PES, PES-NO $\mathrm{N}_{2}$, and PES-NH $\mathrm{N}_{2}$.

The XRD data confirmed the chemical compositions of the plan PES- $\mathrm{NH}_{2}$ versus the PES- $\mathrm{NH}_{2}$ in situ and the PES- $\mathrm{NH}_{2}$ ex situ with AC-OOH, as shown in Figure 4a,b, respectively. In Figure $4 a$, the PES- $\mathrm{NH}_{2}$ has an amorphous structure due to the presence of the benzene rings and the ether bonds, which show a broad peak at $2 \theta=21^{\circ}$ that came in agreement with previous data reported [12,15]. Two broad peaks appeared after blending the PES- $\mathrm{NH}_{2}$ with $\mathrm{AC}-\mathrm{OOH}$ at $2 \theta=33^{\circ}$ and $52^{\circ}$, which referred to the presence of $\mathrm{AC}-\mathrm{COOH}$ and their interactions with PES- $\mathrm{NH}_{2}$, observed from the XRD data. The XRD data of PES- $\mathrm{NH}_{2}$ with $\mathrm{AC}-\mathrm{COOH}$ in the ex situ technique did not show any change in the structure as shown in Figure $4 \mathrm{~b}$, in which all the resultant polymers showed only one broad peak at $2 \theta=21^{\circ}$, which is identical to the plan polymer. This suggests that PES-COOH was coated only on the surface of PES- $\mathrm{NH}_{2}$, which appeared in $\mathrm{XRD}$ as one peak since no internal interaction was formed between the polymer and $\mathrm{AC}-\mathrm{COOH}$ particles.

The thermogravimetric analysis (TGA) of the PES- $\mathrm{NH}_{2}$ (control), as well as $\mathrm{PES}-\mathrm{NH}_{2}$ in situ and ex situ with $\mathrm{AC}-\mathrm{COOH}$, was performed with a heating rate at $10{ }^{\circ} \mathrm{C} / \mathrm{min}$ and under nitrogen flow. The TGA curves of PES- $\mathrm{NH}_{2}$ with different concentrations of $\mathrm{AC}-\mathrm{COOH}$ underflow through the in situ technique appeared to be different from the plan PES- $\mathrm{NH}_{2}$ curve as shown in Figure $5 \mathrm{a}$, whereas Figure $5 b$ shows the derivative thermogravimetric (DTG) analysis for the maximum weight loss. The differences of these curves are because there were variations in the chemical structures between the control (PES- $\mathrm{NH}_{2}$ ) and PES- $\mathrm{NH}_{2}$ with $2 \%, 5 \%, 10 \%$, and $20 \%$ of $\mathrm{AC}-\mathrm{COOH}$ using in the in situ method caused by the noncovalent strong interactions, which, in turn, also seem to decompose differently as they appeared in Figure 5a. As the concentration of activated carbon increases, a better thermal stability was noticed as shown in Table 1 . The maximum weight loss in the control was at $320^{\circ} \mathrm{C}$ whereas the PES- $\mathrm{NH}_{2}$ with $20 \% \mathrm{AC}-\mathrm{COOH}$ was at the higher temperature of $340{ }^{\circ} \mathrm{C}$. In addition, the control was decomposed $\left(T_{50}\right)$ at a lower temperature, around $529^{\circ} \mathrm{C}$, while the decomposition of the PES- $\mathrm{NH}_{2}$ with $20 \%$ AC-COOH was improved to be at $839^{\circ} \mathrm{C}$. The thermal stability of the PES- $\mathrm{NH}_{2}$ in situ with $20 \%$ AC-COOH improved significantly in comparison to the control (Table 1). The strong interactions formed during the synthesis between $\mathrm{AC}-\mathrm{OOH}$ and $\mathrm{PES}-\mathrm{NH}_{2}$ have an impact in increasing the thermal stability of the polymer, which was in agreement with a previous study [16], whereby an increase in the thermal stability of the activated carbon occurred when it was blended with cellulose acetate versus the thermal stability of activated carbon only. 


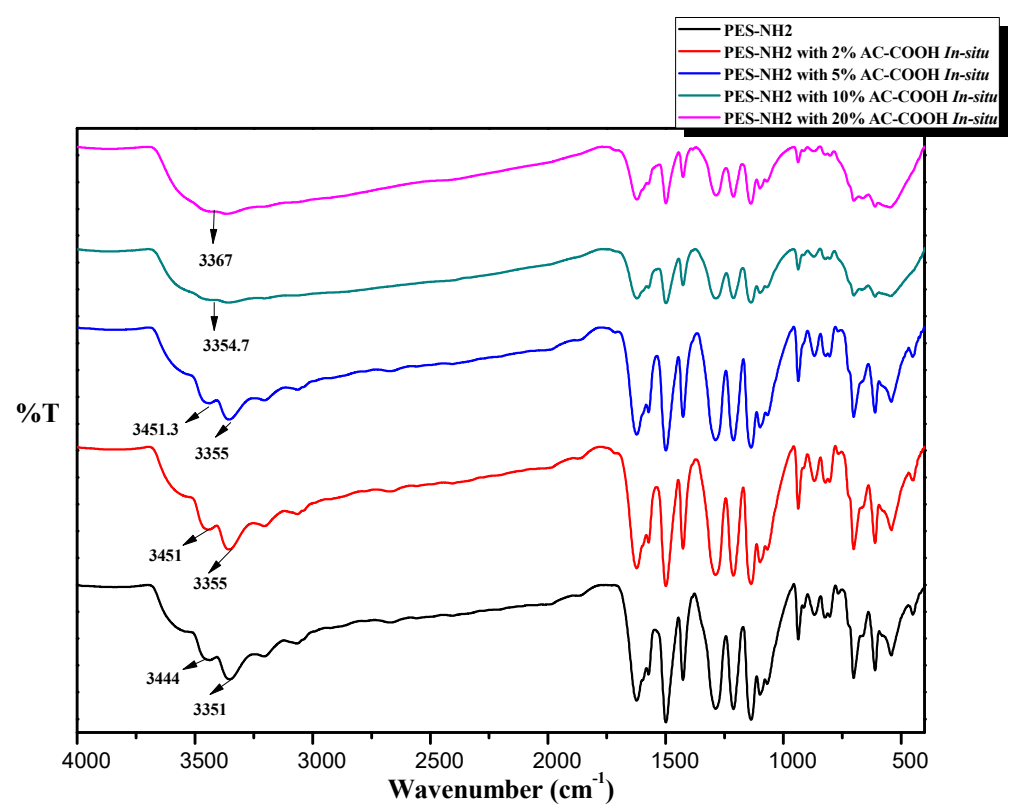

(a)

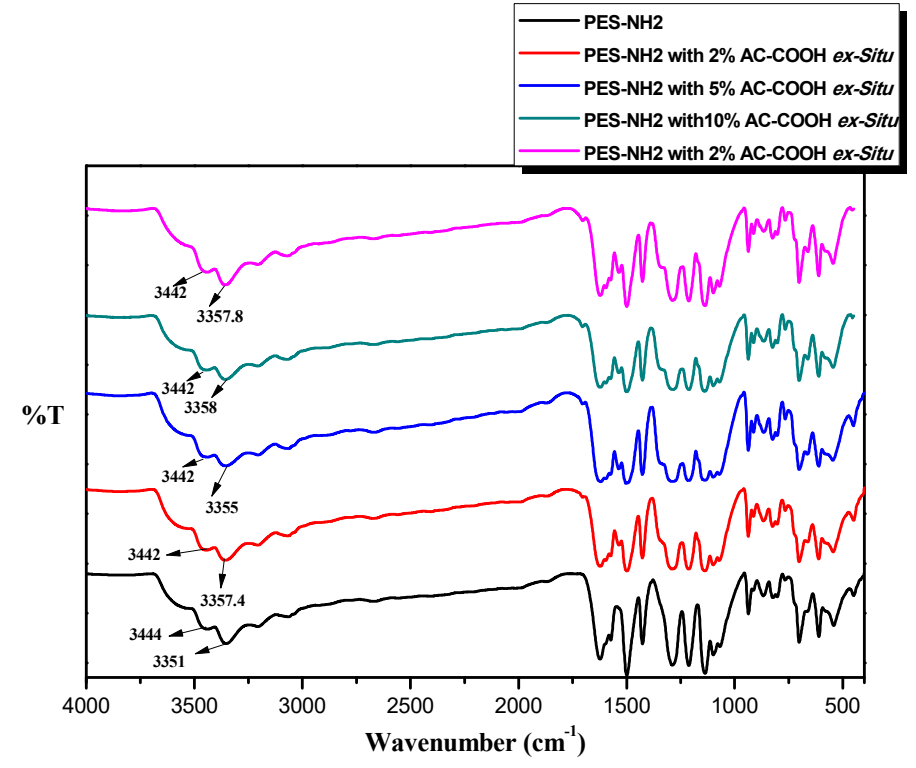

(b)

Figure 3. The FT-IR spectrum of PES- $\mathrm{NH}_{2}$ versus $\mathrm{PES}-\mathrm{NH}_{2}$ with $2 \%, 5 \%$, and $10 \%$ of $\mathrm{AC}-\mathrm{COOH}$ using the (a) in situ and (b) ex situ techniques.

Table 1. The thermal behavior of $\mathrm{PES}-\mathrm{NH}_{2}$ with $\mathrm{AC}-\mathrm{COOH}$ using the in situ technique.

\begin{tabular}{|c|c|c|c|c|c|}
\hline \multirow[t]{2}{*}{ Products } & \multirow[t]{2}{*}{$\begin{array}{l}\mathrm{CDT}_{\text {max }}{ }^{\mathrm{a}} \\
\quad\left({ }^{\circ} \mathrm{C}\right)\end{array}$} & \multirow{2}{*}{$\begin{array}{l}\mathrm{CDT}_{\text {Final }}{ }^{\mathrm{b}} \\
\quad\left({ }^{\circ} \mathrm{C}\right)\end{array}$} & \multicolumn{3}{|c|}{$\begin{array}{l}\text { Temperature }\left({ }^{\circ} \mathrm{C}\right) \text { for Various } \\
\text { Percentage Decompositions }\end{array}$} \\
\hline & & & $T_{10}$ & $T_{25}$ & $T_{50}$ \\
\hline PES-NH ${ }_{2}$ (control) & 320 & 850 & 293 & 331 & 529 \\
\hline PES- $\mathrm{NH}_{2}$ with $2 \% \mathrm{AC}-\mathrm{COOH}$ & 333 & 850 & 298 & 339 & 676 \\
\hline PES-NH ${ }_{2}$ with $5 \%$ AC-COOH & 338 & 850 & 224 & 359 & 647 \\
\hline PES-NH ${ }_{2}$ with $10 \%$ AC-COOH & 340 & 850 & 128 & 435 & 800 \\
\hline PES-NH ${ }_{2}$ with $20 \%$ AC-COOH & 340 & 850 & 127 & 551 & 839 \\
\hline
\end{tabular}

a Determined from the DTG curves. ${ }^{\mathrm{b}}$ The values were determined by the TGA at a heating rate of $10^{\circ} \mathrm{C} \cdot \mathrm{min}^{-1}$. 

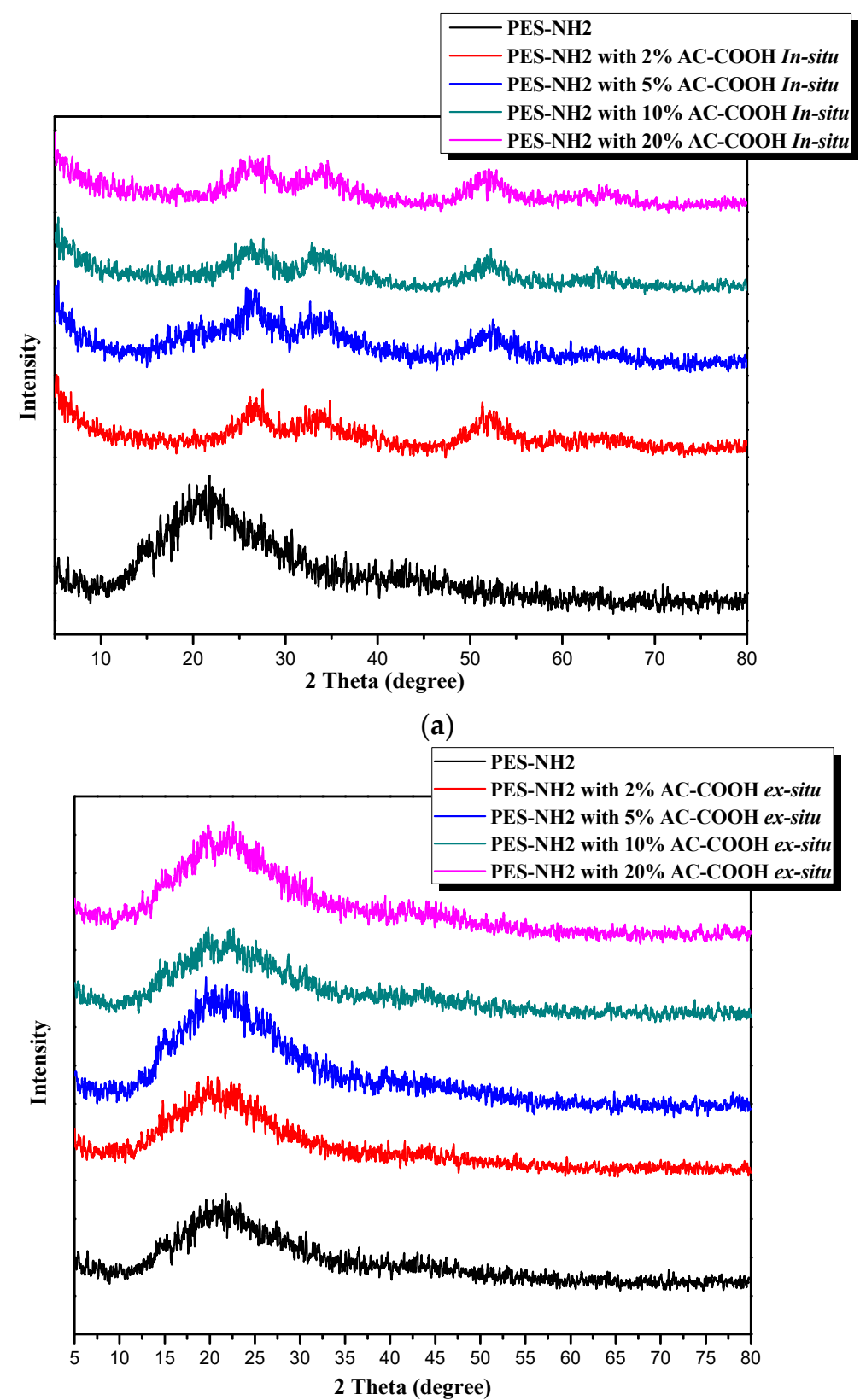

(b)

Figure 4. The XRD of PES- $\mathrm{NH}_{2}$ with $2 \%, 5 \%$, and $10 \%$ of $\mathrm{AC}-\mathrm{COOH}$ with $2 \%, 5 \%, 10 \%$, and $20 \%$ of $\mathrm{AC}-\mathrm{COOH}$ in the (a) in situ and (b) ex situ methods.

On the other hand, the addition of $\mathrm{AC}-\mathrm{COOH}$ to $\mathrm{PES}-\mathrm{NH}_{2}$ using the ex situ method, as shown in Figure $5 c, d$, improved the thermal stability in a way less than in the in situ method, but with a higher thermal stability in comparison to with the control. This came in agreement with the XRD data, which showed a slight change in the chemical structures between the control and the PES- $\mathrm{NH}_{2}$ with AC-COOH by the ex situ method. Table 2 shows the enhancement of the thermal stability of the PES- $\mathrm{NH}_{2}$ ex situ with $\mathrm{AC}-\mathrm{COOH}$ in which the temperature of the maximum weight loss was $337^{\circ} \mathrm{C}$ for the addition of $20 \%$ of $\mathrm{AC}-\mathrm{COOH}$ to the PES- $\mathrm{NH}_{2}$ whereas it was only $320^{\circ} \mathrm{C}$ for the control. The decomposition of half the weight of the polymer $\left(T_{50}\right)$ was only $534^{\circ} \mathrm{C}$ for the control while it was $677^{\circ} \mathrm{C}$ for the PES- $\mathrm{NH}_{2}$ ex situ with $20 \% \mathrm{AC}-\mathrm{COOH}$. 
Table 2. The thermal behavior of $\mathrm{PES}-\mathrm{NH}_{2}$ with $\mathrm{AC}-\mathrm{COOH}$ using the ex situ technique.

\begin{tabular}{|c|c|c|c|c|c|}
\hline \multirow[t]{2}{*}{ Products } & \multirow{2}{*}{$\begin{array}{l}\mathrm{CDT}_{\text {max }}{ }^{\mathrm{a}} \\
\quad\left({ }^{\circ} \mathrm{C}\right)\end{array}$} & \multirow{2}{*}{$\begin{array}{l}\mathrm{CDT}_{\text {Final }} \mathrm{b} \\
\left({ }^{\circ} \mathrm{C}\right)\end{array}$} & \multicolumn{3}{|c|}{$\begin{array}{l}\text { Temperature }\left({ }^{\circ} \mathrm{C}\right) \text { for Various } \\
\text { Percentage Decompositions }\end{array}$} \\
\hline & & & $T_{10}$ & $T_{25}$ & $T_{50}$ \\
\hline PES-NH ${ }_{2}$ (control) & 320 & 850 & 314 & 336 & 534 \\
\hline PES- $\mathrm{NH}_{2}$ with $2 \% \mathrm{AC}-\mathrm{COOH}$ & 331 & 850 & 314 & 355 & 555 \\
\hline PES- $\mathrm{NH}_{2}$ with $5 \%$ AC-COOH & 333 & 850 & 313 & 355 & 518 \\
\hline PES-NH $\mathrm{NH}_{2}$ with $10 \%$ AC-COOH & 337 & 850 & 307 & 346 & 605 \\
\hline PES-NH $\mathrm{NH}_{2}$ with $20 \%$ AC-COOH & 337 & 850 & 303 & 346 & 677 \\
\hline
\end{tabular}

a Determined from the DTG curves. ${ }^{\mathrm{b}}$ The values were determined by TGA at the heating rate of $10^{\circ} \mathrm{C} \cdot \mathrm{min}^{-1}$ under the nitrogen flow.

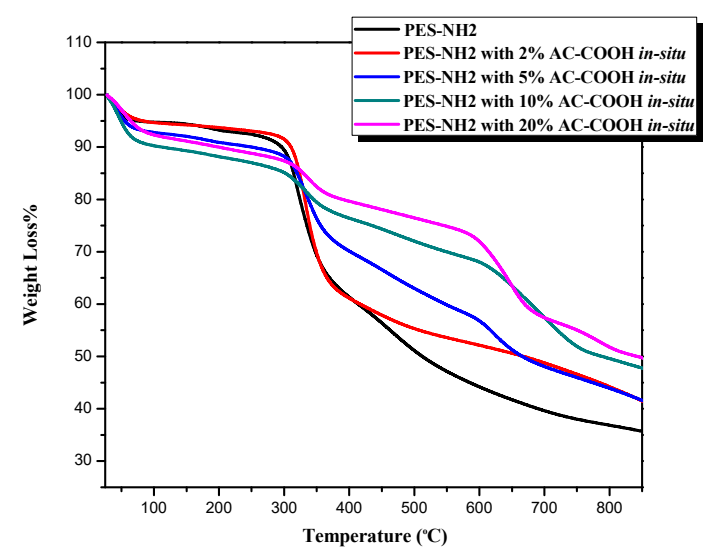

(a)

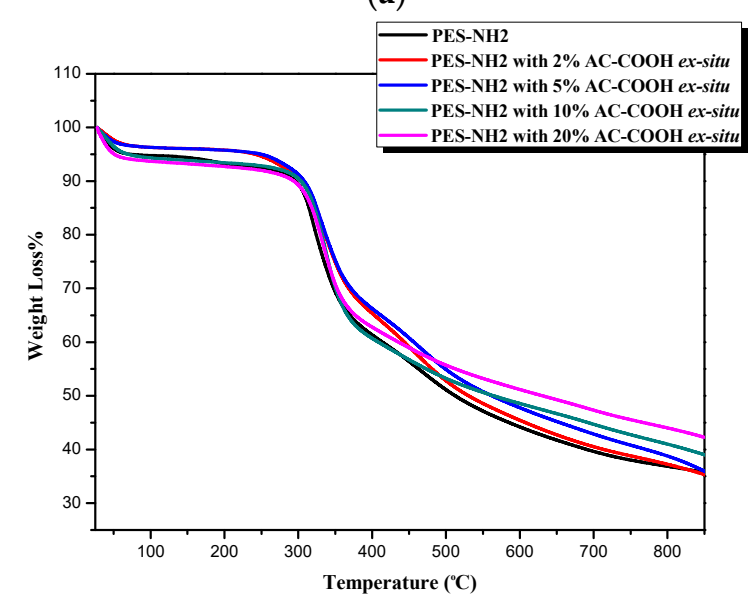

(c)

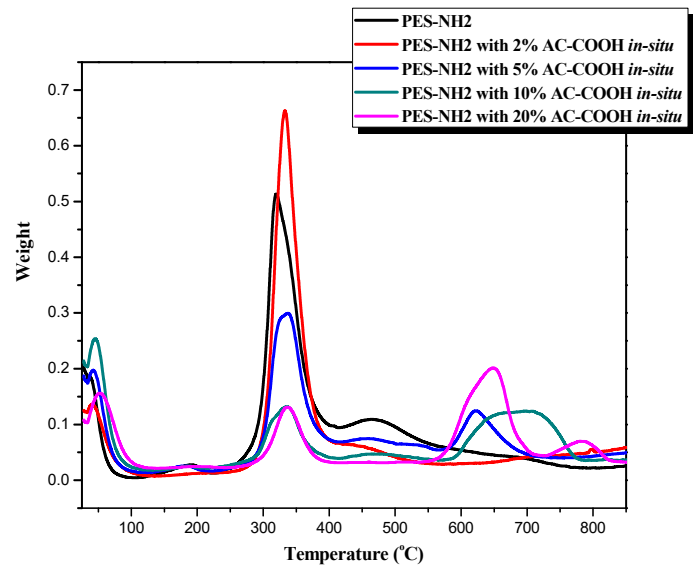

(b)

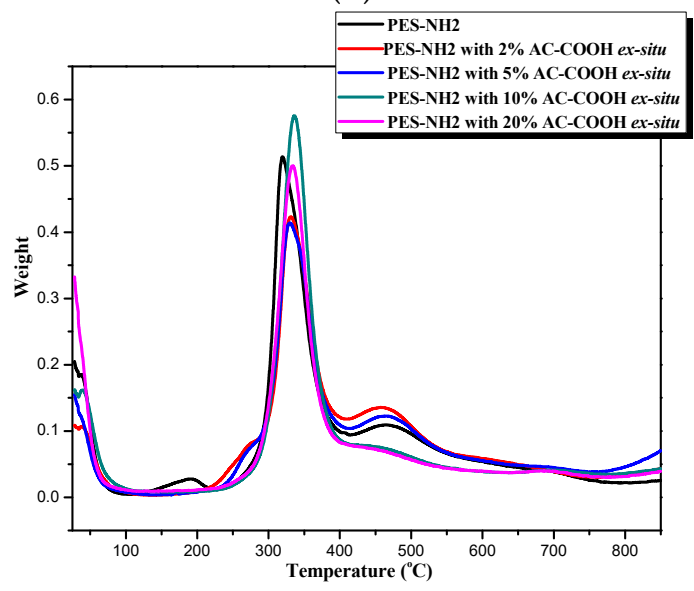

(d)

Figure 5. The TGA and DTG curves of PES- $\mathrm{NH}_{2}$ (control) versus PES- $\mathrm{NH}_{2}$ with different concentrations of $\mathrm{AC}-\mathrm{COOH}$ in the in situ technique: $(\mathbf{a}, \mathbf{b})$; and the ex situ technique: $(\mathbf{c}, \mathbf{d})$.

The morphology of PES- $\mathrm{NH}_{2}$ versus the PES- $\mathrm{NH}_{2}$ with $10 \% \mathrm{AC}-\mathrm{COOH}$ in situ and ex situ are shown in Figure 6 on both the micro- and nanolevels. The SEM images show that PES- $\mathrm{NH}_{2}$ (control) and the structural features of the $\mathrm{PES}-\mathrm{NH}_{2}$ with $\mathrm{AC}-\mathrm{COOH}$ ex situ are similar, while the $\mathrm{PES}-\mathrm{NH}_{2}$ with AC-COOH in situ are different. The SEM images exhibited aggregations in the particles of PES- $\mathrm{NH}_{2}$ with $\mathrm{AC}-\mathrm{COOH}$ in situ, which clearly indicates that the in situ technique alters the morphological structure of the polymer unlike the ex situ method, which did not show any noticeable change on the morphology of PES- $\mathrm{NH}_{2}$ in comparison with the control. 


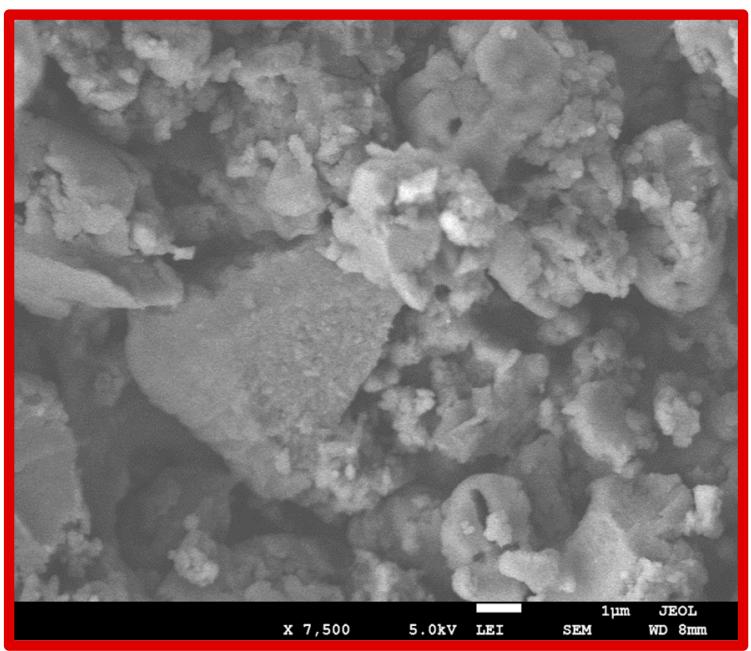

PES-NH $2,1 \mu \mathrm{m} \times 7500$

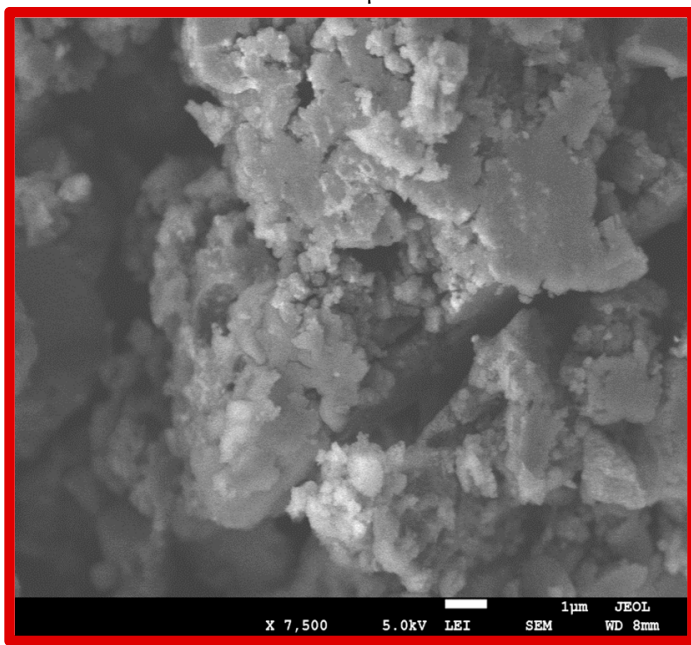

PES-NH$H_{2}$ ex situ with AC-COOH, $1 \mu \mathrm{m} \times 7500$

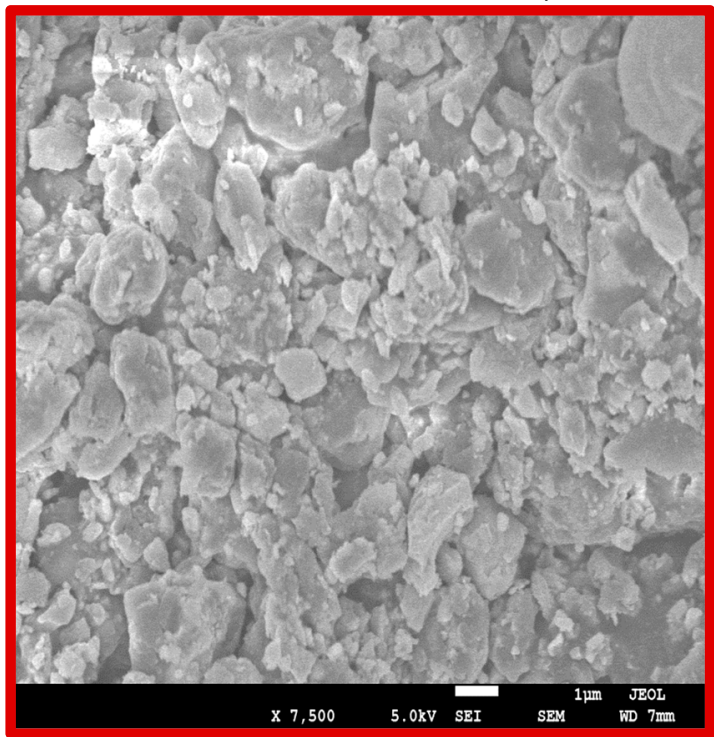

PES-NH ${ }_{2}$ in situ with AC-COOH, $1 \mu \mathrm{m} \times 7500$

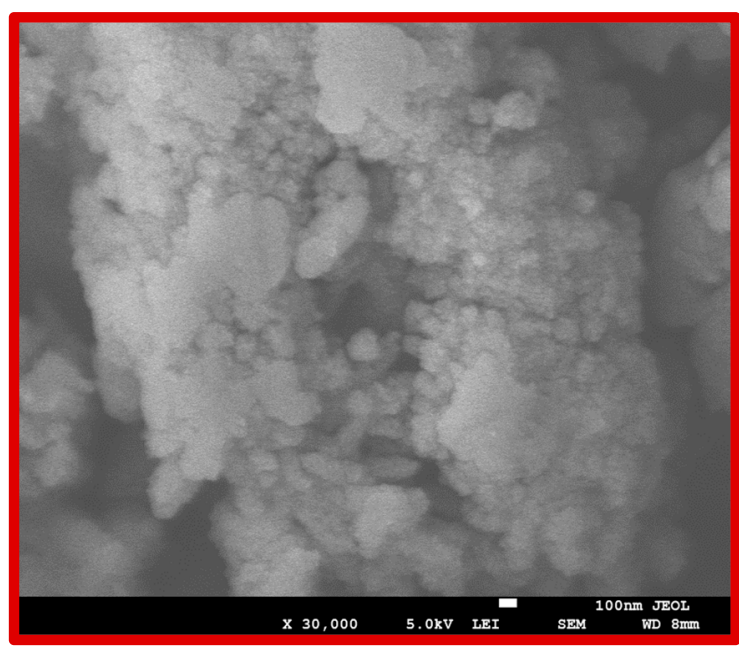

PES-NH2, $100 \mathrm{~nm} \times 30,000$

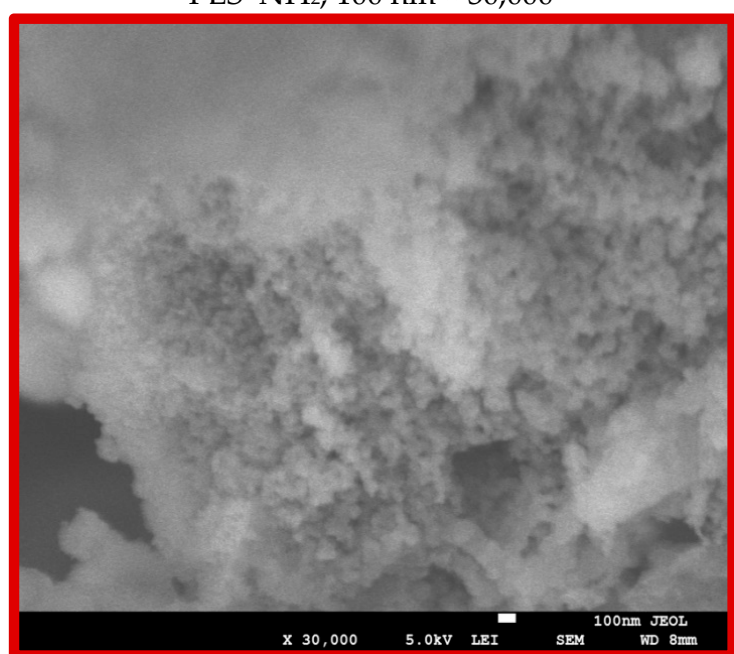

PES-NH 2 ex situ with AC-COOH, $100 \mathrm{~nm} \times 30,000$

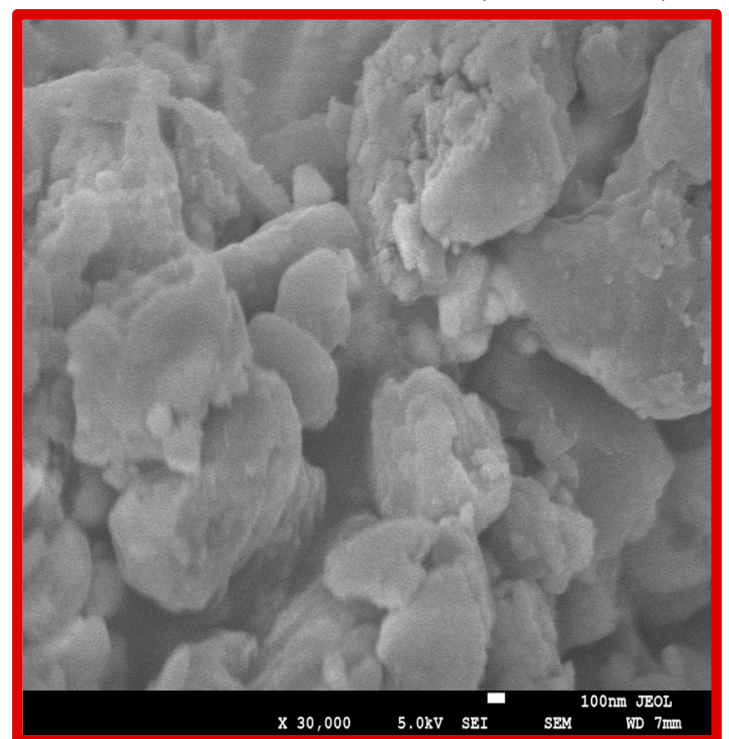

$\mathrm{PES}-\mathrm{NH}_{2}$ in situ with $\mathrm{AC}-\mathrm{COOH}, 100 \mathrm{~nm} \times 30,000$

Figure 6. The SEM of only the PES- $\mathrm{NH}_{2}$, the PES- $\mathrm{NH}_{2}$ with the AC-COOH ex situ, and the PES- $\mathrm{NH}_{2}$ with $\mathrm{AC}-\mathrm{COOH}$ in situ. 


\subsection{The Performance of PES-NH $\mathrm{H}_{2}$ with AC-COOH in Dyes adsorption}

The performance PES- $\mathrm{NH}_{2}$ in situ and ex situ with $\mathrm{AC}-\mathrm{COOH}$ for the adsorption of dyes has been examined. In this work, acid red 1, an anionic dye, was used to test the capabilities of these polymers to adsorb it from aqueous solutions (Figure 7a). As shown in Table 3, as the concentration of AC increased in both techniques, a remarkable increase in the acid red dye adsorption was observed while the control polymer showed the lowest adsorption with only $21 \%$ in comparison with the PES- $\mathrm{NH}_{2}$ in situ and ex situ technique with $20 \%$ AC-COOH, which showed $58 \%$ and $61 \%$ adsorption, respectively. Because PES- $\mathrm{NH}_{2}$ with $20 \%$ AC- $\mathrm{COOH}$ gave the highest percentage of adsorption results in both techniques, these polymers were tested further with methylene blue (Table 4) which is a cationic dye, to examine the performance of these polymers with cationic dyes. As shown in Table 4, $\mathrm{PES}-\mathrm{NH}_{2}$ with $20 \%$ AC-COOH ex situ gave an $88 \%$ adsorption for methylene blue (5 ppm) in comparison with $60 \%$ for acid red $(20 \mathrm{ppm})$. In addition, $\mathrm{PES}-\mathrm{NH}_{2}$ with $20 \% \mathrm{AC}-\mathrm{COOH}$ in situ showed $68 \%$ for methylene blue (5 ppm) and $60 \%$ for acid red (20 ppm) in comparison with the control PES- $\mathrm{NH}_{2}$ that gave $1.6 \%$ only for methylene blue (5 ppm) and $21 \%$ for acid red (20 ppm).<smiles>CC(=O)N(C)c1cc(S(=O)(=O)[O-])cc2c1C(=O)/C(=N\N(C)c1ccccc1)C(S(=O)(=O)[O-])=C2</smiles>

(a)<smiles>CN(C)c1ccc2nc3ccc(=[N+](C)C)cc-3sc2c1</smiles>

(b)

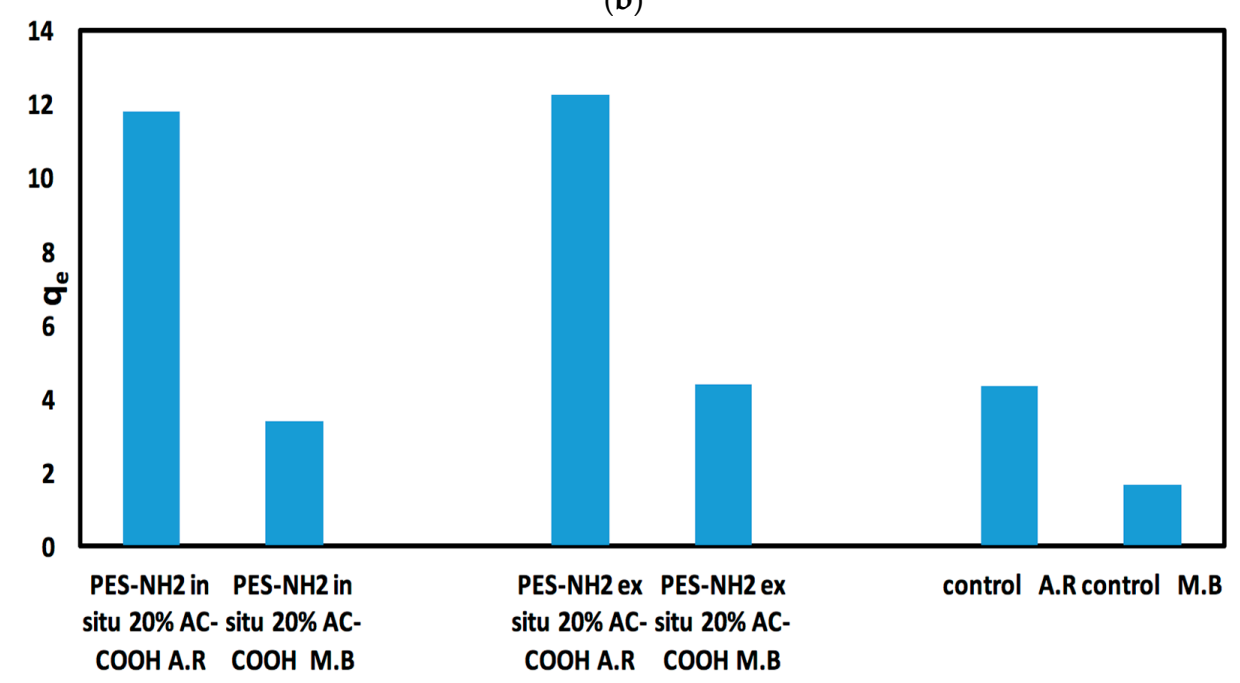

(c)

Figure 7. The chemical structure of acid red 1 (a), methylene blue (b), and their adsorption capacity $\left(q_{\mathrm{e}}\right)$ by both PES- $\mathrm{NH}_{2}$ with $\mathrm{AC}-\mathrm{COOH}$ using the in situ and ex situ techniques in comparison with the control $\left(\mathrm{PES}-\mathrm{NH}_{2}\right)(\mathbf{c})$ at $\mathrm{pH}=2$ for acid red and $\mathrm{pH}=9$ for methylene blue. 
Table 3. The percentage adsorption of acid red (A.R) by PES-NH $\mathrm{N}_{2}$ with different concentrations of $\mathrm{AC}-\mathrm{COOH}$ using the in situ and ex situ techniques; $V=10 \mathrm{~mL}$, acid red conc. $=20$ ppm, polymer wt. $=10 \mathrm{mg}, \lambda=530 \mathrm{~nm}$, $t=20^{\circ} \mathrm{C}$, and $\mathrm{pH}=2$.

\begin{tabular}{|c|c|c|}
\hline Polymers & \%Adsorption of A.R & $q_{\mathrm{e}}$ (mg dye/g adsorbent) \\
\hline Control (PES-NH ${ }_{2}$ ) & 21.749 & 4.3498 \\
\hline PES- $\mathrm{NH}_{2}$ with $2 \%$ AC-COOH in situ & 42.60 & 4.9202 \\
\hline PES- $\mathrm{NH}_{2}$ with $5 \%$ AC-COOH in situ & 35.538 & 7.1076 \\
\hline PES-NH ${ }_{2}$ with $10 \%$ AC-COOH in situ & 37.332 & 7.4664 \\
\hline PES-NH ${ }_{2}$ with $20 \%$ AC-COOH in situ & 60.969 & 12.194 \\
\hline PES- $\mathrm{NH}_{2}$ with $2 \%$ AC-COOH ex situ & 26.457 & 5.2915 \\
\hline PES-NH $\mathrm{NH}_{2}$ with $5 \% \mathrm{AC}-\mathrm{COOH}$ ex situ & 36.996 & 7.3991 \\
\hline PES-NH ${ }_{2}$ with $10 \%$ AC-COOH ex situ & 40.471 & 8.0942 \\
\hline PES- $\mathrm{NH}_{2}$ with $20 \%$ AC-COOH ex situ & 61.323 & 12.265 \\
\hline
\end{tabular}

Table 4. The percentage adsorption of methylene blue (M.B) by PES- $\mathrm{NH}_{2}$ with different concentrations of $\mathrm{AC}-\mathrm{COOH}$ using the in situ and ex situ techniques; $V=10 \mathrm{~mL}$, acid red conc. $=20 \mathrm{ppm}$, polymer wt. $=10 \mathrm{mg}$, $\lambda=530 \mathrm{~nm}, t=20^{\circ} \mathrm{C}$, and $\mathrm{pH}=9$.

\begin{tabular}{|c|c|c|}
\hline Polymers & \%Adsorption of M.B & $q_{\mathrm{e}}$ (mg dye/g adsorbent) \\
\hline Control (PES-NH ${ }_{2}$ ) & 33.861 & 1.6931 \\
\hline PES- $\mathrm{NH}_{2}$ with $20 \%$ AC-COOH in situ & 68.453 & 3.4227 \\
\hline PES- $\mathrm{NH}_{2}$ with $20 \%$ AC-COOH ex situ & 88.063 & 4.4032 \\
\hline
\end{tabular}

Overall, both PES- $\mathrm{NH}_{2}$ with $\mathrm{AC}-\mathrm{COOH}$ in situ and ex situ showed excellent adsorption rates with both the acid red (anionic) and methylene blue (cationic) dyes in comparison with the control as shown in Table 3 and 4, respectively. However, because acid red $(20 \mathrm{ppm})$ showed a good adsorption capacity $\left(q_{\mathrm{e}}\right)$ up to 12 (Figure $7 \mathrm{c}$ ) in comparison with methylene blue (5 ppm) which gave $q_{\mathrm{e}}$ between 3 and 4 for PES- $\mathrm{NH}_{2}$ with AC-COOH in situ and ex situ (Figure 7c), the effect of different impact factors (including $\mathrm{pH}$, temperature, time, and mass) was further examined on the adsorption of acid red dye by $\mathrm{PES}-\mathrm{NH}_{2}$ in situ and ex situ with AC-COOH.

\subsection{Retention Outline of Acid Red from the Aqueous Solution onto Solid Phases PES-NH $\mathrm{H}_{2}$ with In Situ and Ex Situ $\mathrm{AC}-\mathrm{COOH}$}

The adsorption of acid red dye in an aqueous medium with different $\mathrm{pH}$ values using $\mathrm{PES}-\mathrm{NH}_{2}$ in situ and ex situ with $\mathrm{AC}-\mathrm{COOH}$ solid phase were investigated at r.t and after $1 \mathrm{~h}$ of shaking. At equilibrium, the acid red quantity in the aqueous medium was photometrically measured [11]. It was observed when the $\% \mathrm{E}$ was measured for the acid red adsorption onto the $\mathrm{AC}-\mathrm{COOH}$ in situ and ex situ, there was a remarkable reduction in $\% \mathrm{E}$ as the $\mathrm{pH}$ values increased as shown in Figure 8a. Therefore, from this $\mathrm{pH}$ study, it was found that the $\mathrm{pH}$ values in the range of $1-2$ were the best $\mathrm{pH}$ conditions to adsorb the acid red dye from the aqueous medium. The $\mathrm{pH}$ value of 1.5 , which was obtained using $\mathrm{HCl}$, was chosen for this current work.

The second impact factor was the contact time of the red acid analyte and $\mathrm{PES}-\mathrm{NH}_{2}$ with $\mathrm{AC}-\mathrm{COOH}$ solid phase adsorbent. Figure $8 \mathrm{~b}$ shows the investigation study of the effect of the contact time for acid red dye adsorption by $\mathrm{PES}-\mathrm{NH}_{2}$ with $\mathrm{AC}-\mathrm{COOH}$ in situ and ex situ. In this figure, there was an increase in the adsorption process when the contact time was increased. After $40 \mathrm{~min}$ of contact time, most of the acid red dye was adsorbed into the polymer solid phase. However, when the contact time was prolonged, an equilibrium of the percentage of adsorption (in $120 \mathrm{~min}$ ) was observed. As shown in Figure $8 \mathbf{b}$, it can be clearly seen that there were two consecutive steps needed for the adsorption of acid red on $\mathrm{PES}-\mathrm{NH}_{2}$ with $20 \%$ of $\mathrm{AC}-\mathrm{COOH}$, in situ and ex situ. The first step was the fastest, in which the acid red transferred from the solution to the PES- $\mathrm{NH}_{2}$ with a surface of $20 \% \mathrm{AC}-\mathrm{COOH}$ in situ and ex situ whereas the second one was the slowest in which the acid red dye was diffused in the PES- $\mathrm{NH}_{2}$ with bundles of $20 \% \mathrm{AC}-\mathrm{COOH}$ in situ and ex situ. 


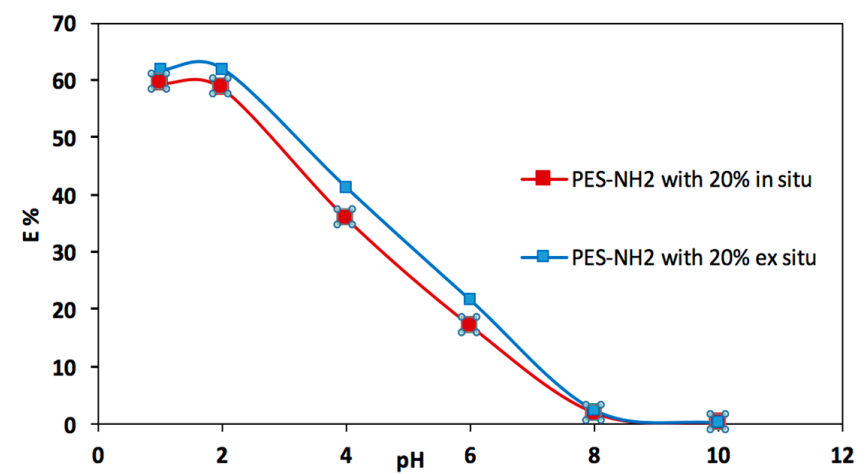

(a)

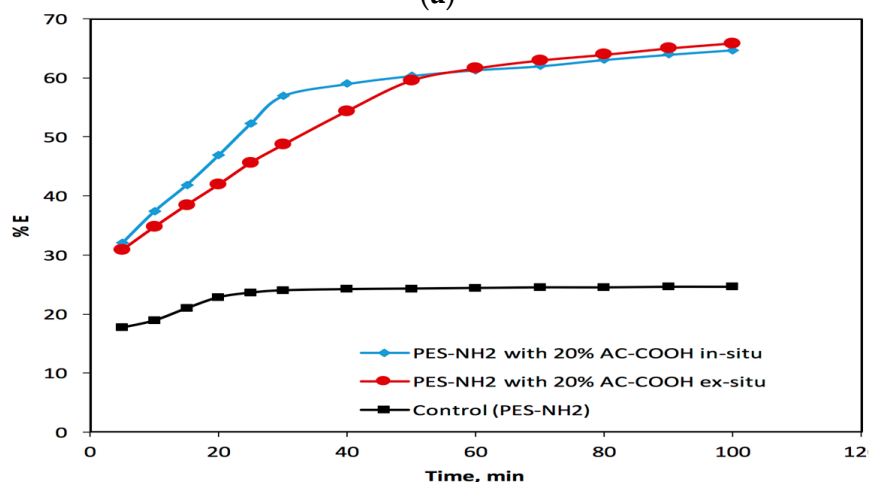

(b)

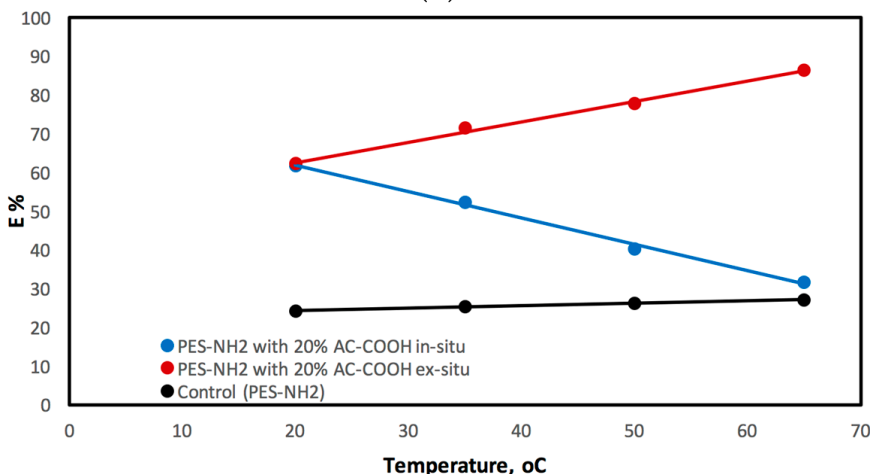

(c)

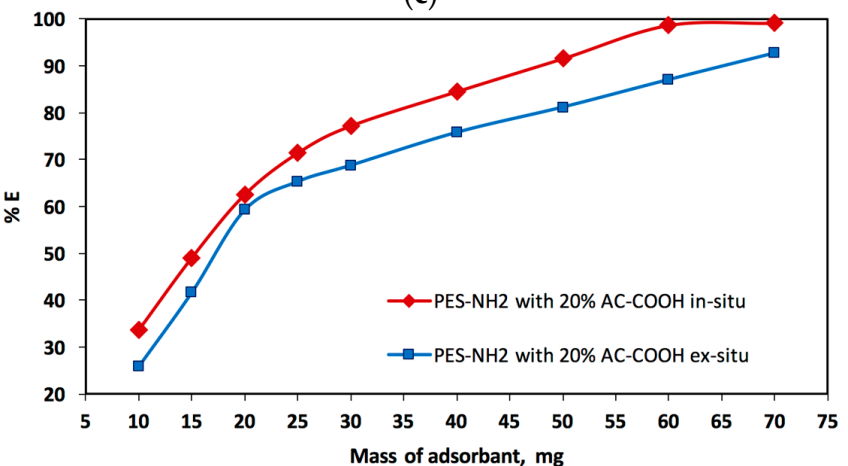

(d)

Figure 8. The effect of the solution $\mathrm{pH}$ with a duration of $1 \mathrm{~h}$ of shaking (a), the shaking time at $\mathrm{pH}=1-2(\mathbf{b})$, the temperature at $20^{\circ} \mathrm{C}, 35^{\circ} \mathrm{C}, 50^{\circ} \mathrm{C}$, and $60^{\circ} \mathrm{C}(\mathrm{c})$, and the masses of the polymer (mg) with a $\mathrm{pH}$ at $1-2$ and a $1 \mathrm{~h}$ shaking time at $20 \pm 0.1{ }^{\circ} \mathrm{C}$ on the adsorption percentage of acid red (20 ppm) from aqueous solutions onto the $\mathrm{PES}-\mathrm{NH}_{2}$ in situ with $\mathrm{AC}-\mathrm{COOH}$ (in red color) and the $\mathrm{PES}-\mathrm{NH}_{2}$ ex situ with $20 \% \mathrm{AC}-\mathrm{COOH}$ (20 mg) (in blue color) with a shaking time of $1 \mathrm{~h}$ at $20 \pm 0.1^{\circ} \mathrm{C}$ (d). 
In addition to the $\mathrm{pH}$ and contact time factors, the third impact factor that affected the adsorption mechanism was the temperature for the sample solutions. The impact of $20^{\circ} \mathrm{C}, 35^{\circ} \mathrm{C}, 50^{\circ} \mathrm{C}$, and $65^{\circ} \mathrm{C}$ temperatures were chosen in this work in order to investigate the impact of these temperatures on the adsorption of acid red dye by the polymer solid phase. As shown in Figure $8 c$, there was a remarkable increase in \%adsorption for the acid red dye by $\mathrm{PES}-\mathrm{NH}_{2}$ with the $20 \% \mathrm{AC}-\mathrm{COOH}$ in situ and ex situ solid phase. However, PES- $\mathrm{NH}_{2}$ with $20 \%$ AC-COOH in situ showed a reversed performance; meaning, as the solution temperature increased, the percentage of acid red adsorption decreased. The results for this adsorption process in Figure $8 \mathrm{c}$ clearly showed the different thermodynamic behavior of $\mathrm{PES}-\mathrm{NH}_{2}$ with $20 \% \mathrm{AC}-\mathrm{COOH}$ in situ, which showed an endothermic nature in comparison with PES- $\mathrm{NH}_{2}$ with $20 \%$ AC-COOH ex situ, which showed an exothermic nature similar to the control (PES-NH $\mathrm{N}_{2}$ ).

Lastly, the effect of the mass on \%adsorption for the acid red adsorbed from the liquid medium was examined with an acid red concentration of $20 \mathrm{mg} / \mathrm{L}$ (Figure $8 \mathrm{~d}$ ). Figure $8 \mathrm{~d}$ shows that the \%adsorption for the acid red dye that was adsorbed from the liquid medium raised as the PES- $\mathrm{NH}_{2}$ with $20 \% \mathrm{AC}-\mathrm{COOH}$ in situ and ex situ doses increased. This increase in the percentage is because of increasing number of activated carbon sites in the PES- $\mathrm{NH}_{2}$ surface/matric for adsorbing the acid red dye from the aqueous medium. The VIS spectrum of the acid red recorded in the aqueous medium exhibited an absorption peak at $530 \pm 2 \mathrm{~nm}$ as shown in Figure 9. However, this peak decreased dramatically after shaking with $\mathrm{PES}-\mathrm{NH}_{2}$ with $20 \% \mathrm{AC}-\mathrm{COOH}$ (Figure 9), and this behavior confirms the efficiency of PES- $\mathrm{NH}_{2}$ in situ and ex situ with $20 \%$ AC-COOH for the acid red dye adsorption from the liquid medium.

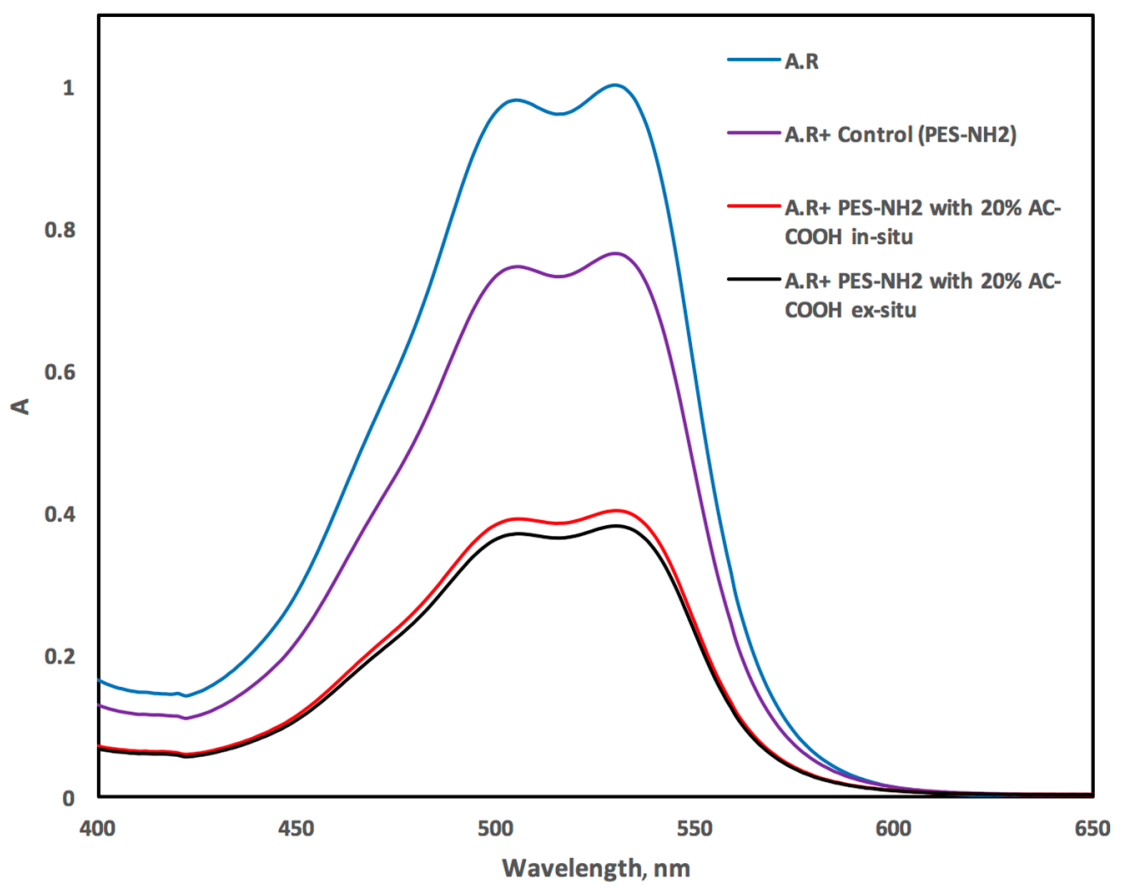

Figure 9. The visible spectra of $20 \mathrm{ppm}$ concentration of acid red in the aqueous phase (blue line),

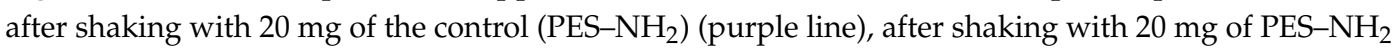
in situ with $20 \% \mathrm{AC}-\mathrm{COOH}$ (red line), and after shaking with $20 \mathrm{mg}$ of $\mathrm{PES}-\mathrm{NH}_{2}$ ex situ with $20 \%$ AC-COOH (black line).

\subsection{The Adsorption Kinetic Performance for the Acid Red Dye by PES-NH $\mathrm{H}_{2}$ with In Situ and Ex Situ} $20 \%$ AC-COOH

The adsorption kinetics of acid red from aqueous solutions by PES- $\mathrm{NH}_{2}$ with the AC-COOH solid phase is necessary to deeply understand the adsorption reactions and the adsorption mechanisms. 
The intraparticle dispersal and film dispersal are two important factors that the retention of acid red adsorption on PES- $\mathrm{NH}_{2}$ with the $\mathrm{AC}-\mathrm{COOH}$ solid phase relies on, and the faster the factor is, the likelier it will be the one that will govern the overall transport percentage.

The acid red adsorbed process half-life time $\left(t_{1 / 2}\right)$ by PES- $\mathrm{NH}_{2}$ with the AC-COOH solid phase from the aquatic medium was determined by plotting $\log C / C_{\mathrm{o}}$ versus time as shown in Figure 10a, in which $C$ and $C_{\mathrm{o}}$ are the red acid dye initial quantity before and after it was adsorbed, respectively. The value of $t_{1 / 2}$ was found to be $1.71 \pm 0.07 \mathrm{~min}$ for PES- $\mathrm{NH}_{2}$ in situ with $20 \% \mathrm{AC}-\mathrm{COOH}$ and $1.83 \pm 0.06$ for PES-NH ex situ with $20 \% \mathrm{AC}-\mathrm{COOH}$ and $1.46 \pm 0.04$ for the control $\left(\mathrm{PES}-\mathrm{NH}_{2}\right)$. This came in agreement with the values of $t_{1 / 2}$ reported recently [17]. Consequently, the kinetics of acid red adsorption onto $\mathrm{PES}-\mathrm{NH}_{2}$ with $\mathrm{AC}-\mathrm{COOH}$ adsorbent relies on both the intraparticle dispersal and film dispersal, in which the faster the factor is, the likelier it will be that the factor will govern the overall transport percentage.

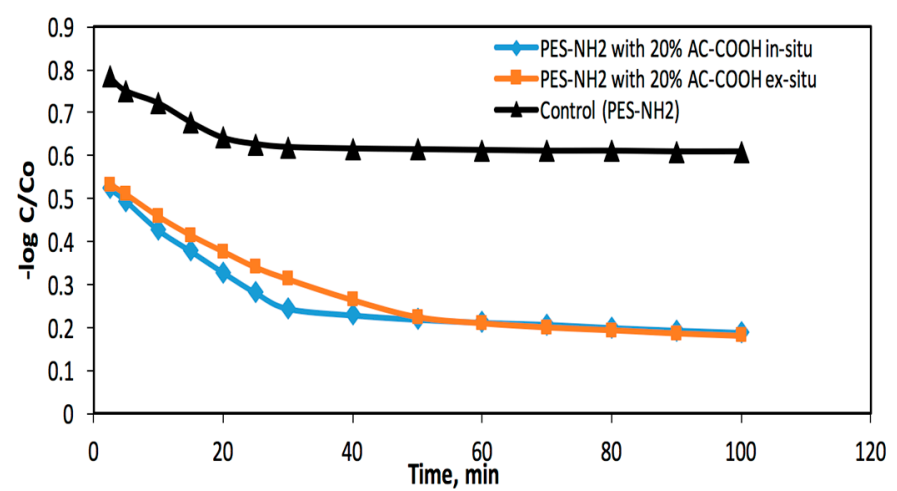

(a)

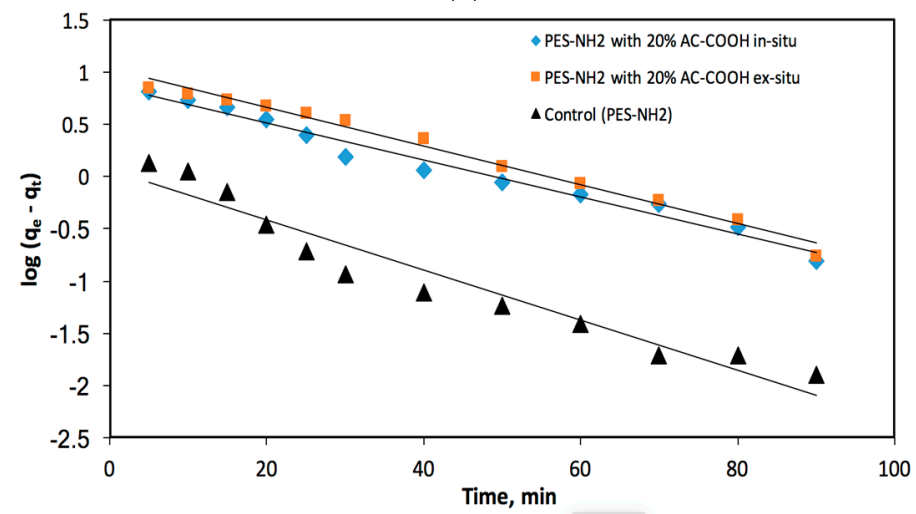

(b)

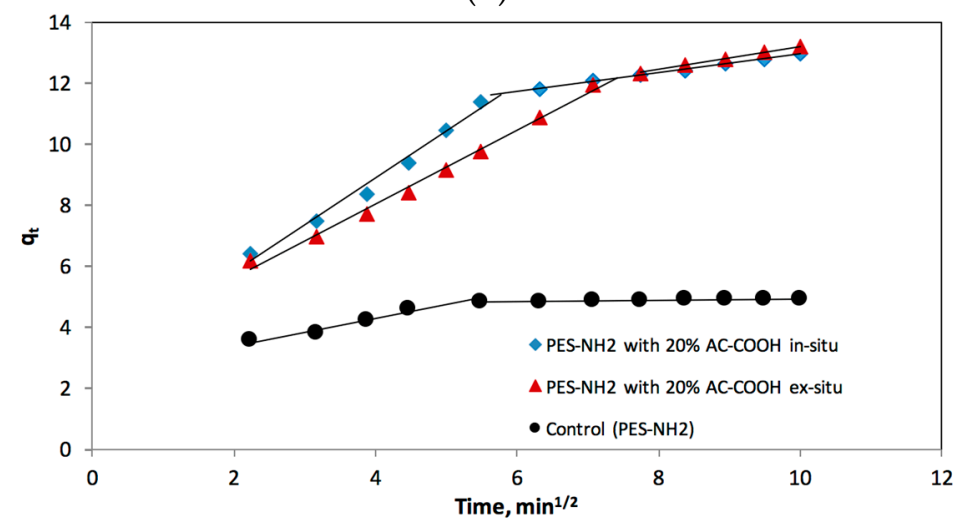

(c)

Figure 10. Cont. 


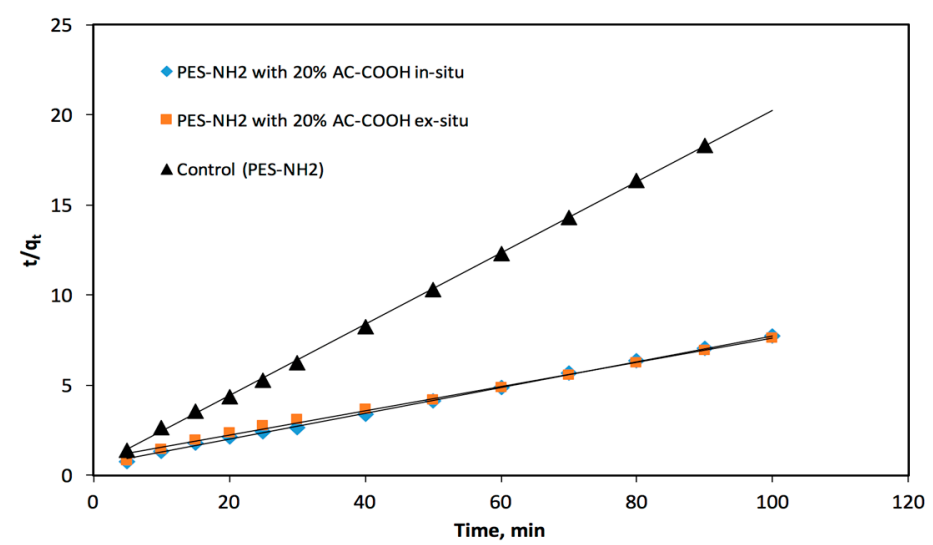

(d)

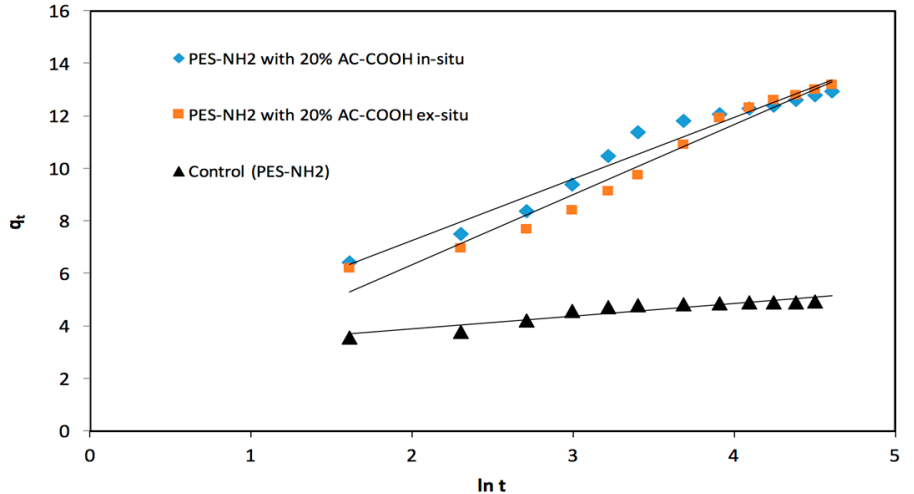

(e)

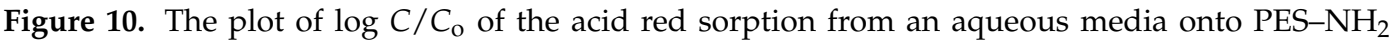
in situ with $20 \% \mathrm{AC}-\mathrm{COOH}, \mathrm{PES}-\mathrm{NH}_{2}$ ex situ with $20 \% \mathrm{AC}-\mathrm{COOH}$, and the control $\left(\mathrm{PES}-\mathrm{NH}_{2}\right)$ versus time (a), Weber-Morris plot of the sobbed acid red onto PES- $\mathrm{NH}_{2}$ in situ with $20 \% \mathrm{AC}-\mathrm{COOH}$, PES- $\mathrm{NH}_{2}$ ex situ with $20 \% \mathrm{AC}-\mathrm{COOH}$, and the control $\left(\mathrm{PES}-\mathrm{NH}_{2}\right)$ versus the square root of time (b), the Lagergren plot of the sorbed acid red onto PES- $\mathrm{NH}_{2}$ in situ with $20 \%$ AC-COOH, PES- $\mathrm{NH}_{2}$ ex situ with $20 \% \mathrm{AC}-\mathrm{COOH}$, and the control (PES- $\mathrm{NH}_{2}$ versus time at $20{ }^{\circ} \mathrm{C}(\mathrm{c})$ ), pseudo-second-order plot of acid red uptake onto PES- $\mathrm{NH}_{2}$ with $20 \% \mathrm{AC}-\mathrm{COOH}$ in situ, $\mathrm{PES}-\mathrm{NH}_{2}$ with $20 \% \mathrm{AC}-\mathrm{COOH}$ ex situ, and the control (PES- $\mathrm{NH}_{2}$ versus time at $20{ }^{\circ} \mathrm{C}(\mathbf{d})$ ), and the Elovich model plot for acid red uptake onto PES- $\mathrm{NH}_{2}$ in situ with $20 \%$ AC-COOH, PES- $\mathrm{NH}_{2}$ ex situ with $20 \% \mathrm{AC}-\mathrm{COOH}$, and the control $\left(\mathrm{PES}-\mathrm{NH}_{2}\right)\left(q_{\mathrm{t}}\right)$ against $(\operatorname{lnt})$ at $20^{\circ} \mathrm{C}(\mathbf{e})$.

The adsorption of acid red species on the PES- $\mathrm{NH}_{2}-\mathrm{AC}-\mathrm{COOH}$ solid phase was tested with a model developed by Weber and Morris [18]:

$$
q_{\mathrm{t}}=R_{\mathrm{d}}(t)^{1 / 2}
$$

$q_{\mathrm{t}}$ is the acid red adsorption concentration in respect to time $(t)$, and $R_{\mathrm{d}}$ refers to intra-particle transport rate values. The $q_{\mathrm{t}}$ versus time plot was presented in Figure $10 \mathrm{~b}$. The values of $R_{\mathrm{d}}$ were calculated from the two distinct slopes of the Weber-Morris plots (Figure 10b). For PES-NH $\mathrm{NH}_{2}$ in situ with $20 \% \mathrm{AC}-\mathrm{COOH}$, the values were found to be about 1.536 and $0.307 \mathrm{mg} / \mathrm{g}$ while, for PES- $\mathrm{NH}_{2}$ ex situ with $20 \% \mathrm{AC}-\mathrm{COOH}$, the values were found to be about 1.207 and $0.421 \mathrm{mg} / \mathrm{g}$, but for the control (PES- $\mathrm{NH}_{2}$ ), the values were found to be about 0.424 and $0.025 \mathrm{mg} / \mathrm{g}$, respectively.

The Lagergren equation is a well-known equation which defines the adsorption rate for aqueous phase systems. The variation of the acid red dye adsorption from liquid solutions onto $\mathrm{PES}-\mathrm{NH}_{2}$ with $\mathrm{AC}-\mathrm{COOH}$ was also tested with a Lagergren equation [19]:

$$
\log \left(q_{\mathrm{e}}-q_{\mathrm{t}}\right)=\log q_{\mathrm{e}}-K_{\text {lager }} \cdot t / 2.303
$$


The $q_{\mathrm{e}}$ stands for the acid red dye quantity that was adsorbed at equilibrium per sorbent mass, whereas $K_{\text {Lager }}$ stands for the first order total rate values for the retention mechanism, and $t$ indicates the time. The $\log \left(q_{\mathrm{e}}-q_{\mathrm{t}}\right)$ versus the time plot in Figure 10c was not a straight line and the calculated value of $K_{\text {Lager }}$ and $q_{\mathrm{e}}$ were found to be about $0.041 \mathrm{~min}^{-1}$ and $7.43 \mathrm{mg} / \mathrm{g}$ for PES- $\mathrm{NH}_{2}$ with $20 \% \mathrm{AC}-\mathrm{COOH}$ in situ, respectively, with a correlation coefficient of $R^{2}=0.978$, while the values for $\mathrm{PES}^{-\mathrm{NH}_{2}}$ with $20 \% \mathrm{AC}-\mathrm{COOH}$ ex situ were found to equal $0.043 \mathrm{~min}^{-1}$ and $10.68 \mathrm{mg} / \mathrm{g}$, respectively, with a correlation coefficient of $R^{2}=0.987$. For the control (PES-NH $\mathrm{N}_{2}$ ), the values were about $0.055 \mathrm{~min}^{-1}$ and $1.16 \mathrm{mg} / \mathrm{g}$, respectively, with a correlation coefficient of $R^{2}=0.937$. All this data and the comparison between the calculated value of $q_{\mathrm{e}}$ with that measured experimentally $\left(q_{\mathrm{e}, \text { exp }}\right)$ confirmed that the first order kinetic model is not a suitable model to describe the adsorption of acid red species onto the used PES- $\mathrm{NH}_{2}$ with AC-COOH sorbent.

The pseudo-second-order model has been investigated as a Langmuir kinetics type [19], taking into consideration two factors: the first is that the analyte concentration with respect to time is a constant and the second factor is that the binding sites rely on the analyte adsorbed quantity at equilibrium. The pseudo-second-order linear equation was stated as follows:

$$
\frac{t}{q_{\mathrm{t}}}=\frac{1}{h}+\left(\frac{1}{q_{\mathrm{e}}}\right) t
$$

where $h$ is equal to $k_{2} q_{\mathrm{e}}^{2}$ which refers to the initial adsorption level, whereas $q_{\mathrm{e}}$ and $q_{\mathrm{t}}$ are the quantity of adsorbed analyte per mass unit at any selected time at equilibrium. Under these conditions, the $\frac{t}{q_{t}}$ versus the time $(t)$ plot was applied as shown in Figure 10d, in which it was shown as linear. Then, from the slope and intercept, the second order constant $\left(k_{2}\right)$ and equilibrium capacity $\left(q_{\mathrm{e}}\right)$ were obtained first for PES- $\mathrm{NH}_{2}$ with $20 \% \mathrm{AC}-\mathrm{COOH}$ in situ and they were found to equal $8.84 \times 10^{-3} \mathrm{~g} \cdot(\mathrm{mg} \cdot \mathrm{min})^{-1}$ and $13.95 \mathrm{mg} / \mathrm{g}$, respectively, with an excellent correlation $\left(R^{2}=0.999\right)$, while for PES- $\mathrm{NH}_{2}$ with $20 \% \mathrm{AC}-\mathrm{COOH}$ ex situ, they were found to be equal to $5.3 \times 10^{-3} \mathrm{~g} \cdot(\mathrm{mg} \cdot \mathrm{min})^{-1}$ and $14.79 \mathrm{mg} / \mathrm{g}$, respectively, with an excellent correlation $\left(R^{2}=0.995\right)$. For the control $\left(\mathrm{PES}-\mathrm{NH}_{2}\right)$, the $k_{2}$ and $q_{\mathrm{e}}$ values were found to be equal to $8.8 \times 10^{-2} \mathrm{~g} \cdot(\mathrm{mg} \cdot \mathrm{min})^{-1}$ and $5.05 \mathrm{mg} / \mathrm{g}$, respectively, with a superb correlation $\left(R^{2}=0.999\right)$. It is clearly seen from these reported data that all the experimental measured values were considered suitable values. The pseudo-second-order rate constant $\left(k_{2}\right)$ values rely on different experimental factors including the initial PES- $\mathrm{NH}_{2}-\mathrm{AC}-\mathrm{COOH}$ concentration, the $\mathrm{pH}$ values, as well as the temperature [19].

The adsorption capacity rate is usually determent using the Elovich equation [19]. This equation is appropriate mostly for systems that show kinetics of chemisorptions and it can be also applied to a system in which the adsorbent surface area is heterogeneous. This equation can be calculated as follows:

$$
q_{\mathrm{t}}=\beta \ln (\alpha \beta)+\beta \ln t
$$

The $\alpha$ value $\left(\mathrm{g} \cdot \mathrm{mg}^{-1} \cdot \mathrm{min}^{-1}\right)$ stands for the original adsorption rate value whereas the $\beta$ value $\left(\mathrm{mg} \cdot \mathrm{g}^{-1} \cdot \mathrm{min}^{-1}\right)$ stands for the coefficient of desorption. The $q_{\mathrm{t}}$ against the $\ln t$ plot was applied as shown Figure 10e and the relationship between them was linear. The Elovich factors (the $\alpha$ as well as $\beta$ values) were calculated from the intercepts and the slopes obtained from Figure 10e. These values for the acid red dye were found to be about $1.12 \mathrm{~g} \cdot \mathrm{mg}^{-1} \cdot \mathrm{min}^{-1}$ and $2.345 \mathrm{mg} \cdot \mathrm{g}^{-1} \cdot \mathrm{min}^{-1}$, respectively, adsorbed onto $\mathrm{PES}-\mathrm{NH}_{2}$ with $20 \% \mathrm{AC}-\mathrm{COOH}$ in situ, and they were found to be about $0.542 \mathrm{~g} \cdot \mathrm{mg}^{-1} \cdot \mathrm{min}^{-1}$ and $2.671 \mathrm{mg} \cdot \mathrm{g}^{-1} \cdot \mathrm{min}^{-1}$, respectively, adsorbed onto PES- $\mathrm{NH}_{2}$ with $20 \%$ AC-COOH ex situ. Meanwhile, the $\alpha, \beta$ values were found to equal $712.8 \mathrm{~g} \cdot \mathrm{mg}^{-1} \cdot \mathrm{min}^{-1}$ and $0.493 \mathrm{mg} \cdot \mathrm{g}^{-1} \cdot \mathrm{min}^{-1}$, respectively adsorbed onto the control $\left(\mathrm{PES}-\mathrm{NH}_{2}\right.$ ).

The above experimental data measured from different kinetic models (including the pseudofirst-order kinetic (Lagergren), the pseudo-second-order kinetic, as well as the Elovich kinetic) were applied and used in order to determine the kinetic behaviors of the acid red dye adsorption. From the comparisons between the experimental and calculated values of $q_{\mathrm{e}}$ as well as the values of the correlation coefficients that were all determined from these three models as summarized in Table 5, it can be seen 
that the most suitable model for the kinetic behavior of the acid red dye that was adsorbed on PES- $\mathrm{NH}_{2}$ with the $\mathrm{AC}-\mathrm{COOH}$ solid phase was the pseudo-second-order kinetic model.

Table 5. The different kinetic models' parameters for the adsorption of acid red on PES- $\mathrm{NH}_{2}$ in situ with $20 \%$ AC-COOH, PES- $\mathrm{NH}_{2}$ ex situ with $20 \% \mathrm{AC}-\mathrm{COOH}$, and the control $\left(\mathrm{PES}-\mathrm{NH}_{2}\right)$ at $293 \mathrm{~K}$.

\begin{tabular}{|c|c|c|c|c|}
\hline $\begin{array}{l}\text { The pseudo-first-order kinetic } \\
\text { (Lagregen) model }\end{array}$ & $q_{\mathrm{e}, \exp }(\mathrm{mg} / \mathrm{g})$ & $q_{\mathrm{e}, \text { calc }}(\mathrm{mg} / \mathrm{g})$ & $\begin{array}{c}k_{1}, \\
\mathrm{~g} \cdot(\mathrm{mg} \cdot \mathrm{min})^{-1}\end{array}$ & $R^{2}$ \\
\hline PES-NH ${ }_{2}$ (Control) & 4.92 & 1.16 & 0.055 & 0.937 \\
\hline Control in situ with $20 \% \mathrm{ACOOH}$ & 12.94 & 7.43 & 0.041 & 0.978 \\
\hline Control ex situ with $20 \%$ ACOOH & 13.18 & 10.68 & 0.043 & 0.987 \\
\hline The pseudo-second-order kinetic model & $q_{\mathrm{e}, \exp }(\mathrm{mg} / \mathrm{g})$ & $q_{\mathrm{e}, \text { calc }}(\mathrm{mg} / \mathrm{g})$ & $\begin{array}{c}k_{2}, \\
\mathrm{~g} \cdot(\mathrm{mg} \cdot \mathrm{min})^{-1}\end{array}$ & $R^{2}$ \\
\hline PES-NH ${ }_{2}$ (Control) & 4.92 & 5.05 & $8.8 \times 10^{-2}$ & 0.999 \\
\hline Control in situ with $20 \% \mathrm{ACOOH}$ & 12.94 & 13.95 & $8.84 \times 10^{-3}$ & 0.999 \\
\hline Control ex situ with $20 \% \mathrm{ACOOH}$ & 13.18 & 14.79 & $5.3 \times 10^{-3}$ & 0.995 \\
\hline Elovich kinetic model & $\begin{array}{c}\alpha, \\
\left(\mathrm{g} \cdot \mathrm{mg}^{-1} \cdot \min ^{-1}\right)\end{array}$ & $\left(\mathrm{mg} \cdot \mathrm{g}^{-1} \cdot \min ^{-1}\right)$ & - & $R^{2}$ \\
\hline PES-NH ${ }_{2}$ (Control) & 712.8 & 0.493 & - & 0.871 \\
\hline Control in situ with $20 \% \mathrm{ACOOH}$ & 1.12 & 2.345 & - & 0.962 \\
\hline Control ex situ with $20 \% \mathrm{ACOOH}$ & 0.542 & 2.671 & - & 0.97 \\
\hline
\end{tabular}

\subsection{Thermodynamic Characteristics of Acid Red Retention onto the Solid Phase}

The adsorption of acid red onto PES- $\mathrm{NH}_{2}$ with the AC-COOH solid phase was investigated with various temperatures between $293 \mathrm{~K}$ and $338 \mathrm{~K}$ in order to find the acid red retention values of these polymers. The thermodynamic factors including $\Delta H, \Delta S$, and $\Delta G$ were determined by utilizing the below equations [20]:

$$
\begin{aligned}
\ln K c & =\frac{-\Delta H}{R T}+\frac{\Delta S}{R} \\
\Delta G & =\Delta H-T \Delta S \\
\Delta G & =-R T \ln K c
\end{aligned}
$$

The $\Delta H$ stands for enthalpy, $\Delta S$ refers to the entropy, and $\Delta G$ defines the Gibbs free energy variations. T refers to the temperature in the Kelvin system, whereas the gas constant is abbreviated as $R\left(\approx 8.314 \mathrm{~J} \cdot \mathrm{K}^{-1} \cdot \mathrm{mol}^{-1}\right)$. The equilibrium constant $\left(K_{\mathrm{c}}\right)$ relies on the adsorption mechanism for the fractional attainment which is abbreviated as Fe. The $K_{\mathrm{c}}$ values were calculated in order to determine the acid red dye retention on the PES- $\mathrm{NH}_{2}$ with the $\mathrm{AC}-\mathrm{COOH}$ solid sorbent at equilibrium the below equation:

$$
K_{\mathrm{c}}=\frac{q_{\mathrm{e}}}{1-q_{\mathrm{e}}}
$$

The $\ln K_{\mathrm{c}}$ versus 1000/T plot was applied for the retention of acid red dye onto the solid phase of PES- $\mathrm{NH}_{2}$ with AC-COOH, in which the relationship was found to be linear as shown in Figure 11 with various temperatures between 293 and $338 \mathrm{~K}$. From Figure 11, it can be seen that both the control $\left(\mathrm{PES}-\mathrm{NH}_{2}\right)$ and the PES- $\mathrm{NH}_{2}$ with $20 \% \mathrm{AC}-\mathrm{COOH}$ ex situ equilibrium constants increased when the temperature increased, which suggest that that the acid red dye retention on the solid phase sorbents is an endothermic mechanism. However, the PES- $\mathrm{NH}_{2}$ with $20 \% \mathrm{AC}-\mathrm{COOH}$ using the in situ technique equilibrium constant decreased when the temperature increased which suggests that the acid red dye retention on the solid phase sorbents (PES- $\mathrm{NH}_{2}$ in situ with $20 \% \mathrm{AC}-\mathrm{COOH}$ ) is an exothermic mechanism. The $\Delta H, \Delta S$, and $\Delta G$ values that were determined for acid red retention were determined from the $\ln K_{\mathrm{c}}$ versus 1000/T plot utilizing the slopes and intercepts as shown in Figure 11. The $\Delta H, \Delta S$, and $\Delta G$ values for control (PES-NH ${ }_{2}$ ) were found to be around $2.78 \pm 0.1 \mathrm{~kJ} \cdot \mathrm{mol}^{-1}, 0.0025 \pm 0.00003 \mathrm{~J} \cdot \mathrm{mol}^{-1} \cdot \mathrm{K}^{-1}$, and $277 \pm 0.02 \mathrm{~kJ} \cdot \mathrm{mol}^{-1}$ (at $293 \mathrm{~K}$ ), respectively, whereas for PES- $\mathrm{NH}_{2}$ ex situ with $20 \% \mathrm{AC}-\mathrm{COOH}$, 
they were found to be equal to $24.04 \pm 0.5 \mathrm{~kJ} \cdot \mathrm{mol}^{-1}, 85.79 \pm 0.8 \mathrm{~J} \cdot \mathrm{mol}^{-1} \cdot \mathrm{K}^{-1}$, and $-1.1 \pm 0.06 \mathrm{~kJ} \cdot \mathrm{mol}^{-1}$ (at $293 \mathrm{~K}$ ), respectively. However, the values for $\mathrm{PES}-\mathrm{NH}_{2}$ with $20 \% \mathrm{AC}-\mathrm{COOH}$ in situ were found to be $-23.16 \pm 0.4 \mathrm{~kJ} \cdot \mathrm{mol}^{-1},-74.85 \pm 0.6 \mathrm{~J} \cdot \mathrm{mol}^{-1} \cdot \mathrm{K}^{-1}$ and $-1.23 \pm 0.08 \mathrm{~kJ} \cdot \mathrm{mol}^{-1}$ (at $293 \mathrm{~K}$ ), correspondingly. The value of $\Delta H$ for the control (PES- $\mathrm{NH}_{2}$ ) and PES- $\mathrm{NH}_{2}$ ex situ with $20 \% \mathrm{AC}-\mathrm{COOH}$ reveals that the uptake mechanism was endothermic, which exhibits the bond energy variations between the adsorbent solid phase and the analyte. However, the value of $\Delta H$ for $\mathrm{PES}-\mathrm{NH}_{2}$ in situ with $20 \% \mathrm{AC}-\mathrm{COOH}$ reveals that the uptake mechanism was exothermic.

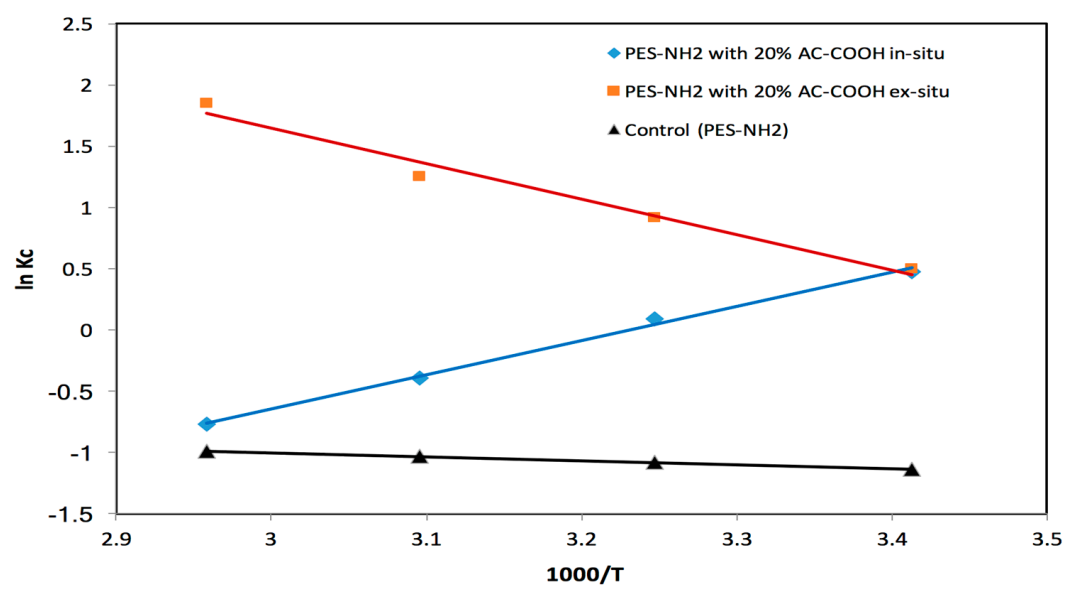

Figure 11. The plot of $\ln K_{\mathrm{c}}$ of acid red sorption from an aqueous media onto PES- $\mathrm{NH}_{2}$ in situ with $20 \%$ AC-COOH, PES- $\mathrm{NH}_{2}$ ex situ with 20\% AC- $\mathrm{COOH}$, and the control solid phase particles versus 1000/T.

The $\Delta S$ positive values indicate there is an increase in the freedom degree at the solid-liquid system during the acid red binding, and this is because of the presence of water molecules that are released by hydration spheres occurred during the adsorption mechanism. On the other hand, the $\Delta S$ negative values indicate that the entropy (reorientation phase) is governed at the activation state and nonelectrostatics interactions between the analyte (acid red dye) and the adsorbed material (PES- $\mathrm{NH}_{2}-\mathrm{AC}-\mathrm{COOH}$ ). In addition, the $\Delta G$ negative values at a temperature of $293 \mathrm{~K}$ for both PES- $\mathrm{NH}_{2}$ with in situ 20\% AC-COOH and PES- $\mathrm{NH}_{2}$ ex situ with $20 \% \mathrm{AC}-\mathrm{COOH}$ indicate that the interactions that form during the adsorption of acid red retention on $\mathrm{PES}-\mathrm{NH}_{2}$ with $\mathrm{AC}-\mathrm{COOH}$ solid phase were spontaneous. In contrast, the positive value of $\Delta G$ at $293 \mathrm{~K}$ for the control (PES- $\mathrm{NH}_{2}$ ) indicates that interactions that form during the adsorption of acid red retention on $\mathrm{PES}-\mathrm{NH}_{2}$ solid phase were nonspontaneous.

\subsection{Environmental Applications}

In order to investigate the efficiency of the PES- $\mathrm{NH}_{2}-\mathrm{AC}-\mathrm{COOH}$ solid phase use in environmental applications, this study used tap water and seawater samples to explore the capability of this polymer in removing red acid dye from these samples. The tap water was obtained from our chemistry tap at King Abdul-Aziz University while the seawater was obtained from the Red Sea at the Jeddah coast in Saudi Arabia, and a deionized water sample was also used as a third sample. For the seawater and tap water samples, the acid red concentrations were below the U.V. detection. Hence, these samples were spiked with acid red dye (20 mg/L) and PES- $\mathrm{NH}_{2}$ ex situ with $20 \% \mathrm{AC}-\mathrm{COOH}(70 \mathrm{mg})$ and PES- $\mathrm{NH}_{2}$ in situ with $20 \% \mathrm{AC}-\mathrm{COOH}(80 \mathrm{mg})$. Under the optimized conditions including a $\mathrm{pH}$ of 1 , a temperature of $293 \mathrm{~K}$, and a $1 \mathrm{~h}$ of shaking time, the percentages of red acid adsorbed from the Red Sea water samples were found to be $92.68 \%$ and $91.91 \%$ for PES- $\mathrm{NH}_{2}$ ex situ with $20 \%$ AC-COOH and PES- $\mathrm{NH}_{2}$ in situ with $20 \% \mathrm{AC}-\mathrm{COOH}$, respectively. The percentages of acid adsorbed from the tap water samples were found to be $96.34 \%$ and $95.94 \%$ for $\mathrm{PES}-\mathrm{NH}_{2}$ ex situ with $20 \% \mathrm{AC}-\mathrm{COOH}$ and PES- $\mathrm{NH}_{2}$ in situ with 20\% AC-COOH, respectively, as shown in Figure 12. 


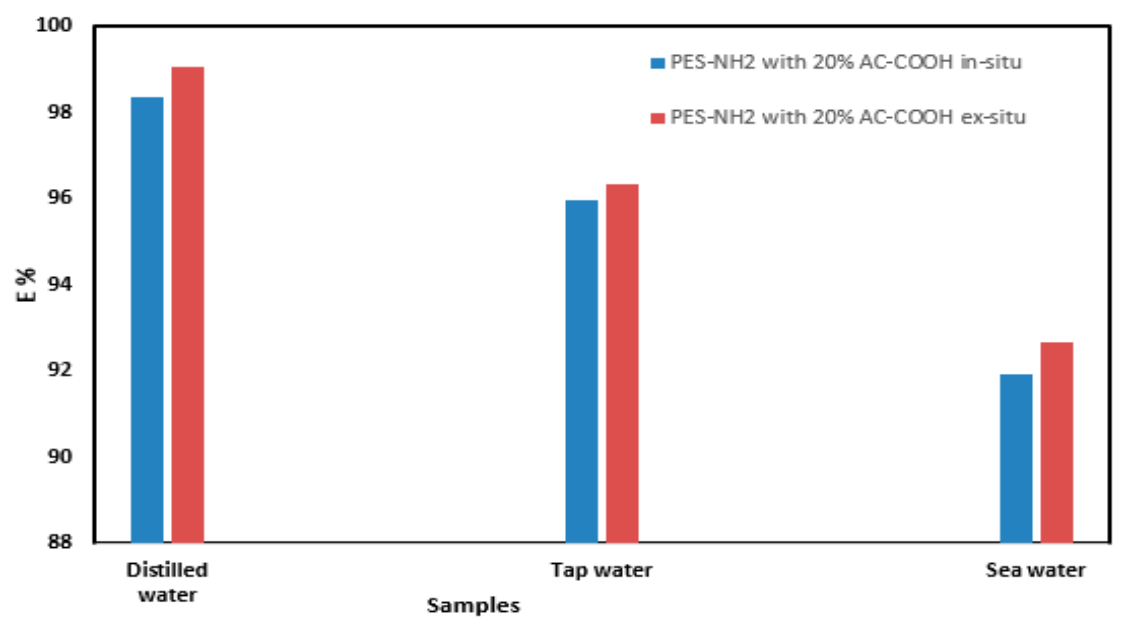

Figure 12. The adsorption percentages of acid red from different real samples by $\mathrm{PES}-\mathrm{NH}_{2}$ with $20 \%$ AC-COOH (experimental conditions: $20 \mathrm{~mL}$ solution, $\mathrm{pH} 1.5,60 \mathrm{~min}, 293 \mathrm{~K}$, acid red concentration $20 \mathrm{mg} \cdot \mathrm{L}^{-1}, 70 \mathrm{mg}$ in the case of PES- $\mathrm{NH}_{2}$ ex situ with $20 \% \mathrm{AC}-\mathrm{COOH}$, and $80 \mathrm{mg}$ in the case of PES- $\mathrm{NH}_{2}$ in situ with $20 \% \mathrm{AC}-\mathrm{COOH}$ ).

In order to test the reusability of the fabricated polymers, the used samples of PES- $\mathrm{NH}_{2}$ with $20 \% \mathrm{AC}-\mathrm{COOH}$ by both ex situ and in situ techniques were cleaned afterward by washing these samples with acetone and left to be dried. Then, the PES- $\mathrm{NH}_{2}$ ex situ and in situ with $20 \% \mathrm{AC}-\mathrm{COOH}$ samples were reused again. The acid red dye was re-adsorbed again (three cycles) with approximately the same adsorption percentage rates as the first time. Therefore, $\mathrm{PES}-\mathrm{NH}_{2}$ with $20 \% \mathrm{AC}-\mathrm{COOH}$ is an efficient method to be reused for more than one cycle as the acid red dye is adsorbed from the aquatic environment without any reduction in its adsorption capability.

\section{Conclusions}

In this current study, PES was chemically modified to $\mathrm{PES}-\mathrm{NH}_{2}$ following a two-step reaction: a nitration reaction followed by a reduction reaction. The chemical modification of PES was introduced in order to overcome the hydrophobicity of this polymer. According to the FT-IR, XRD, and thermal analyses results, when PES- $\mathrm{NH}_{2}$ was in situ with $\mathrm{AC}-\mathrm{COOH}$, there was a difference in the chemical structures of these polymers in comparison with the control, suggesting strong noncovalent interactions between the PES- $\mathrm{NH}_{2}$ and $\mathrm{AC}-\mathrm{COOH}$. Contrary to the in situ technique, the ex situ method of the polymer with $\mathrm{AC}-\mathrm{COOH}$ exhibits a slight change in the chemical structures in comparison to the control. In addition, the dye adsorption results showed excellent adsorption rates of acid dye 1 and methylene blue dyes as the concentrations of $\mathrm{AC}-\mathrm{COOH}$ increased in both in situ and ex situ techniques with PES- $\mathrm{NH}_{2}$. The results also showed the optimized conditions were fundamental factors for maximizing the acid red dye adsorption rate and they were found to be at a $\mathrm{pH}$ of 1.5 , for a duration of $1 \mathrm{~h}$, and at a temperature of $293 \mathrm{~K}$. Additionally, the mass of the $\mathrm{PES}-\mathrm{NH}_{2}-\mathrm{AC}-\mathrm{COOH}$ is a very important factor as the more mass used, the higher the obtained dye adsorption rate. After going through different kinetic models (including the pseudo-first-order kinetic (Lagergren), the pseudo-second-order kinetic, as well as the Elovich kinetic model) to determine the adsorption behavior of the acid red dye, this study's results showed that the pseudo-second-order kinetic model was the most appropriate model for the kinetic behavior of the acid red dye adsorption by PES- $\mathrm{NH}_{2}-\mathrm{AC}-\mathrm{COOH}$.

Author Contributions: N.A.A. carried out the experimental work, collected the data and wrote the manuscript. M.A.H. and K.A.A. designed the research work, explained the results and revised the manuscript. A.M.A. explained the results and revised the manuscript.

Conflicts of Interest: The authors declare no conflicts of interest. 


\section{References}

1. Yangui, R.B.E. Removal of Water Pollutants by Adsorption on Activated Carbon Prepared from Olive-Waste Cakes and by Biological Treatment Using Ligninolytic Fungi. Ph.D. Thesis, Universitat Autònoma de Barcelona, Barcelona, Spain, 2013.

2. Khanna, S.; Rattan, V.K. Removal of acid red 1 from aqueous waste streams using peel of cucumis sativus fruit. Equilibrium studies. J. Chem. Technol. Metall. 2017, 52, 803-811.

3. Gupta, V.K. Application of low-cost adsorbents for dye removal-A review. J. Environ. Manag. 2009, 90, 2313-2342. [CrossRef] [PubMed]

4. Chequer, F.M.D.; de Oliveira, G.A.R.; Ferraz, E.R.A.; Cardoso, J.C.; Zanoni, M.V.B.; de Oliveira, D.P. Textile dyes: Dyeing process and environmental impact. In Eco-Friendly Textile Dyeing and Finishing; InTech: Philadelphia, PA, USA, 2013.

5. Forgacs, E.; Cserhati, T.; Oros, G. Removal of synthetic dyes from wastewaters: A review. Environ. Int. 2004, 30, 953-971. [CrossRef] [PubMed]

6. Homaeigohar, S.; Zillohu, A.U.; Abdelaziz, R.; Hedayati, M.K.; Elbahri, M.A. Novel nanohybrid nanofibrous adsorbent for water purification from dye pollutants. Materials 2016, 9, 848. [CrossRef] [PubMed]

7. Raghuvanshi, S.P.; Singh, R.; Kaushik, C.P.; Raghav, A.K. Kinetics study of methylene blue dye bioadsorption on baggase. Appl. Ecol. Environ. Res. 2004, 2, 35-43. [CrossRef]

8. Wang, T.; Yin, Z.; Wen, X.; Yu, B.; Deng, X.; Zhao, C. Polyethersulfone-activated carbon hybrid particles for phenobarbital removal. Sep. Sci. Technol. 2009, 45, 142-147. [CrossRef]

9. Kim, E.A.; Seyfferth, A.L.; Fendorf, S.; Luthy, R.G. Immobilization of $\mathrm{Hg}(\mathrm{II})$ in water with polysulfide-rubber (PSR) polymer-coated activated carbon. Water Res. 2011, 45, 453-460. [CrossRef] [PubMed]

10. Van der Bruggen, B. Chemical modification of polyethersulfone nanofiltration membranes: A review. J. Appl. Polym. Sci. 2009, 114, 630-642. [CrossRef]

11. Haider, M.S.; Shao, G.N.; Imran, S.M.; Park, S.S.; Abbas, N.; Tahir, M.S.; Kim, H.T. Aminated polyethersulfone-silver nanoparticles (AgNPs-APES) composite membranes with controlled silver ion release for antibacterial and water treatment applications. Mater. Sci. Eng. C 2016, 62, 732-745. [CrossRef] [PubMed]

12. Marwani, H.M.; Albishri, H.M.; Jalal, T.A.; Soliman, E.M. Activated carbon immobilized dithizone phase for selective adsorption and determination of gold(III). Desalin. Water Treat. 2012, 45, 128-135. [CrossRef]

13. Marczenko, Z. Separation and spectrophotometric determination of elements. J. Am. Chem. Soc. 1987, 109. [CrossRef]

14. Şimşek, E.N.; Akdağ, A.; Çulfaz-Emecen, P.Z. Modification of poly(ether sulfone) for antimicrobial ultrafiltration membranes. Polymer 2016, 106, 91-99. [CrossRef]

15. Qu, P.; Tang, H.; Gao, Y.; Zhang, L.; Wang, S. Polyethersulfone composite membrane blended with cellulose fibrils. BioRes 2010, 5, 2323-2336. [CrossRef]

16. Velu, S.; Rambabu, K.; Muruganandam, L. Development, Characterization and Application Studies of Cellulose acetate-activated Carbon blend Ultra Filtration Membranes. Int. J. Chemtech. Res. 2014, 6, 565-577.

17. Palágyi, S.; Braun, T. Separation and preconcentration of trace elements and inorganic species on solid polyurethane foam sorbents. Preconc. Tech. Trace Elem. 1992, 363-400. [CrossRef]

18. Weber, W.J.; Morris, J.C. Kinetics of adsorption on carbon from solution. J. Sanit. Eng. Div. 1963, 89, 31-60.

19. Al-Saidi, H.M.; Abdel-Fadeel, M.A.; El-Sonbati, A.Z.; El-Bindary, A.A. Multi-walled carbon nanotubes as an adsorbent material for the solid phase extraction of bismuth from aqueous media: Kinetic and thermodynamic studies and analytical applications. J. Mol. Liq. 2016, 216, 693-698. [CrossRef]

20. El-Shahawi, M.S.; Othman, M.A.; Abdel-Fadeel, M.A. Kinetics, thermodynamic and chromatographic behaviour of the uranyl ions sorption from aqueous thiocyanate media onto polyurethane foams. Anal. Chim. Acta 2015, 546, 221-228. [CrossRef]

(C) 2018 by the authors. Licensee MDPI, Basel, Switzerland. This article is an open access article distributed under the terms and conditions of the Creative Commons Attribution (CC BY) license (http://creativecommons.org/licenses/by/4.0/). 